Federal Reserve Bank of Minneapolis

Research Department Staff Report 334

March 2004

\title{
U.S. Real Exchange Rate Fluctuations and Relative Price Fluctuations
}

\author{
Caroline M. Betts* \\ University of Southern California \\ Timothy J. Kehoe* \\ University of Minnesota \\ and Federal Reserve Bank of Minneapolis
}

\begin{abstract}
This paper studies the relation between the United States' bilateral real exchange rate and the associated bilateral relative price of nontraded goods for five of its most important trade relationships. Traditional theory attributes fluctuations in real exchange rates to changes in the relative price of nontraded goods. We find that this relation depends crucially on the choice of price series used to measure relative prices and on the choice of trade partner. The relation is stronger when we measure relative prices using producer prices rather than consumer prices. The relation is stronger the more important is the trade relationship between the United States and a trade partner. Even in cases where there is a strong relation between the real exchange rate and the relative price of nontraded goods, however, a large fraction of real exchange rate fluctuations is due to deviations from the law of one price for traded goods.
\end{abstract}

*The first version of this paper was circulated in February 2003. The authors gratefully acknowledge the financial support of the National Science Foundation. We would like to thank Rudolfs Bems, Paul Bergin, Mario Crucini, Mick Devereux, Charles Engel, Gonzalo Fernández de Córdoba, Patrick Kehoe, Kristian Jönsson, Beverly Lapham, and seminar participants at the Federal Reserve Bank of Minneapolis, NYU, Stanford, UC-Davis, UCLA, USC, the 2001 Annual Meeting of the Society for Economic Dynamics in Stockholm, and the 2003 Workshop of the Jornadas Béticas de Macroeconomía Dinámica for very helpful comments and suggestions. We also thank Kim Ruhl and James MacGee for extraordinary research assistance. The views expressed herein are those of the authors and not necessarily those of the Federal Reserve Bank of Minneapolis or the Federal Reserve System. 


\section{INTRODUCTION}

Traditional real exchange rate theory dichotomizes all goods as being either traded or nontraded. Traded goods can be internationally exchanged at negligible cost, and therefore, because of arbitrage, their prices obey the law of one price. Nontraded goods cannot be exchanged in this manner, so their prices are determined by purely domestic factors. This implies that aggregate real exchange rate movements are driven entirely by cross-country movements in the relative prices of nontraded to traded goods within countries (see, for example, Cassel 1918 and Pigou 1923).

The first graph in Figure 1 illustrates the relation between the bilateral real exchange rate for Germany and the United States with a bilateral relative price of nontraded goods. In the graph, $\mathrm{rer}_{\text {ger, }, \text { s }}$ is the logarithm of the real exchange rate between Germany and the United States, and $r e r_{g e r, u s}^{N}$ is the logarithm of the relative price measure. The construction of the variables in the graph is discussed in detail in what follows. What is important at this point is to realize that these variables have been constructed so that, if the traditional theory works well, and if we are using appropriate data to measure relative prices, the two variables should be the same or approximately the same. The first graph in Figure 1 shows no discernible relation at all between the two series. Researchers such as Chari, Kehoe, and McGrattan (2002) use graphs like it to justify an approach that totally abandons the traditional theory and instead focuses on deviations from the law of one price attributable to fluctuations in money supplies across countries when nominal prices are sticky. The second graph in Figure 1, which illustrates the same relation between bilateral variables, in this case for Canada and the United States, indicates that totally abandoning the traditional theory may be premature. Although the traditional theory does not account for all of the fluctuations in the bilateral real exchange rate, there is clearly a significant relation between $\mathrm{rer}_{\text {can,us }}$ and $\mathrm{rer}_{\mathrm{can}, u s}^{\mathrm{N}}$, suggesting that the traditional theory should be modified rather than totally abandoned.

This paper addresses the question: When does the relation between the bilateral real exchange rate and the associated bilateral relative price of nontraded to traded goods look like that in the first graph in Figure 1, the Germany-U.S. graph, and when does it look like that in the second graph, the Canada-U.S. graph? To answer this question, we 
study the bilateral real exchange rates between the United States and five of its most important trade partners over the period 1980-2000 and four different sets of measures of aggregate price levels and relative prices of nontraded goods.

We find that the relation between the bilateral real exchange rate and the relative price of nontraded goods to traded goods is stronger

1. when we use measures of the price of traded goods within each country based on production site values, rather than those based on consumption values - which include the prices of many nontraded wholesale, distribution, and retail services; and

2. when we examine bilateral real exchange rates where the trade relationship between the United States and the trade partner is important for one or both - measured by bilateral trade either as a fraction of GDP or as a fraction of total trade.

Even in cases where there is a strong relation between the real exchange rate and the relative price of nontraded goods, however, we find that a large fraction of real exchange rate fluctuations is due to deviations from the law of one price for traded goods.

There is a substantial amount of modern research that utilizes the traditional theory of real exchange rate determination. The fundamental premise of this theory is that there is a substantial category of goods that are tradable in the sense that their prices closely obey the law of one price because they are, in fact, traded. Balassa $(1961,1964)$ and Samuelson (1964), for example, emphasize cross-country changes in the relative price of nontraded goods that are due to high relative productivity growth in the traded goods sector of comparatively fast-growing countries. More recently, Rebelo and Vegh (1995), Stockman and Tesar (1995), and Fernández de Córdoba and Kehoe (2000) present models in which sector specific productivity shocks, real demand shocks, and changes in the trade regime cause fluctuations in the relative price of nontraded goods across countries that drive fluctuations in the real exchange rate.

Some recent empirical work on deviations from the law of one price for traded goods challenges the relevance of the traditional theory. Evidence assembled by Engel (1993), Lapham (1995), Rogers and Jenkins (1995), Engel and Rogers (1996), and 
Knetter (1997), and earlier by Kravis and Lipsey (1978), shows that there are large and variable deviations from the law of one price for many traded goods in disaggregated price data. More importantly from the point of view of this paper, Rogers and Jenkins (1995), Engel (1999), Obstfeld (2001), and Chari, Kehoe, and McGrattan (2002) show that fluctuations in the relative price of nontraded goods account for less than 10 percent of the fluctuations of real exchange rates in variance decompositions of U.S. bilateral real exchange rates with a number of OECD — and especially European — countries. These variance decompositions imply that not only are there large deviations from the law of one price for traded goods, but that these deviations are as large as, or almost as large as, the corresponding deviations for nontraded goods.

There are, however, at least three important exceptions to these results:

1. When Engel (1999) uses consumer price indices (CPIs) to construct bilateral real exchange rates and the ratio of the $C P I$ to the producer price index (PPI) to measure the relative price of nontraded to traded goods, he finds that fluctuations in the relative price of nontraded goods become more important in accounting for fluctuations in the bilateral real exchange rate for a number of European country-U.S. pairs.

2. Rogers and Jenkins (1995) and Engel (1999) find an important role for the relative price of nontraded goods in accounting for Canada-U.S. real exchange rate variations compared to the European country-U.S. cases.

3. Crucini, Telmer, and Zachariadis (2001) study deviations from the law of one price for more than 5,000 goods and services between countries in the European Union for the years 1975, 1980, 1985, and 1990. They find that the magnitudes of these deviations are systematically related to measures of the tradability of the goods.

Exceptions like these give us clues to the factors that give rise to the two very different relations depicted in Figure 1. Specifically, we ask: Does the relation depend in a systematic way on the price indices used in a manner that has not yet been identified by 
existing studies, and, if so, how? Does this relation between U.S. bilateral real exchange rates and the relative price of nontraded goods depend in a systematic way on the trade partner examined, and, if so, how?

We construct bilateral real exchange rates and relative prices for five major trade partners of the United States - Canada, Germany, Japan, Korea, and Mexico - and for the period 1980-2000. Together, the five bilateral trade relationships between the United States and these countries account for 53 percent of U.S. trade in 2000. We measure real exchange rates using ratios of aggregate price levels adjusted by nominal exchange rates. We measure aggregate price levels using three alternative data series for each country: gross output $(G O)$ deflators, $C P I s$, and personal consumption expenditure deflators $(P C D s)$. As we point out in the next section, to calculate the bilateral relative prices of nontraded goods relevant for determining the real exchange rate, all that we need are an aggregate price level and a traded goods price level. We measure price levels for traded goods using four alternative data series: the $G O$ deflator for relatively traded goods' sectors, the $P P I$, the $C P I$ for all goods (but not services), and the $P C D$ for all commodities (goods). For each of the five bilateral trade relationships and each of the four different ways of measuring relative prices, we summarize the relation between the real exchange rate and the relevant bilateral relative price of nontraded goods. We do so by computing three summary statistics that measure the similarity of comovements and the similarity of magnitudes of movements between the real exchange rate and relative price of nontraded goods.

Our results show that we can reject the strong proposition of the traditional theory that only the relative price of nontraded goods matters for real exchange rate determination. Nevertheless, we find large differences in the relation between the U.S. bilateral real exchange rate and the bilateral relative price of nontraded goods across alternative price measures and across alternative trade partners. For some bilateral trade relationships and some measures of the relative price of nontraded goods, fluctuations in this relative price constitute a large fraction of the fluctuations in the real exchange rate.

Analyzing either the country-specific results or trade weighted averages of the individual country statistics, we find that the values of the summary statistics vary widely across price series. When we use production site price data like $G O$ deflators or PPIs to 
measure traded goods prices, the statistics reveal a more important role for the relative price of nontraded goods in accounting for real exchange rate fluctuations than when we use consumption price data like the components of CPIs or PCDs. We argue that this is because production site data better capture the prices of goods that can be arbitraged across locations. Final consumption price data incorporate a much higher fraction of the prices of nontraded distribution, wholesale, and retail services than do production site prices.

We can account for the cross-trade partner differences in our results largely by the relative size of each country's trade relationship with the United States. The more important is this bilateral relationship to the country, the more closely related are the bilateral real exchange rate and the associated bilateral relative price of nontraded to traded goods. This suggests the existence of an important link between the behavior of international relative prices and the volume of trade flows.

Our work identifies some anomalies relative to previous research that need to be verified by further data analysis and, if robust, need to be accounted for by models. Betts and Kehoe (2004a) extend our analysis to a sample of 50 countries and 1225 bilateral trade relationships, but with less detail on different price series. They find, as here, the stronger is the trade relationship between the two trade partners, the stronger is the relation between the bilateral real exchange rate and the bilateral relative price of nontraded goods. This empirical evidence suggests that we modify the concept of tradability in the traditional theory. In contrast to the traditional theory, we find significant measured bilateral deviations from the law of one price for baskets of goods that are traded, and these deviations play a role in real exchange rate fluctuations. To the extent that these deviations in traded goods prices are systematically smaller than are those in aggregate price levels, however, the relative prices of nontraded to traded goods also play a significant role. The size of this role depends crucially on how much trade two countries conduct with each other - on exactly how much this basket of traded goods is actually traded between them. An obvious possibility is to model goods, or aggregates of goods, that are more traded as being more "tradable" in the sense that they generate smaller deviations from the law of one price. Betts and Kehoe (2004b) develop a theoretical framework in which some types of goods are more tradable than other types. 
They calibrate a dynamic, stochastic general equilibrium model to Mexico-U.S. data and show that it can account for many of the empirical findings that we identify here and in Betts and Kehoe (2004a).

\section{METHODOLOGY}

\subsection{Real Exchange Rate Decomposition}

We calculate the bilateral real exchange rate between the United States and country $i$ as

$$
R E R_{i, u s, t}=N E R_{i, u s, t} \frac{P_{u s, t}}{P_{i, t}},
$$

where $N E R_{i, u s, t}$ denotes the nominal exchange rate in terms of country $i$ currency units per U.S. dollar at date $t, P_{u s, t}$ is a price deflator or index for the basket of goods consumed or produced in the United States, and $P_{i, t}$ is a price deflator or index for the comparable basket of goods in country $i$.

In traditional real exchange rate theory, aggregate price levels are thought of as functions of the prices of both traded and nontraded goods. We denote by $P_{i, t}^{T}$ a price deflator or index for traded goods in country $i$. Multiplying and dividing by the ratio of traded goods prices yields

$$
\operatorname{RER}_{i, u s, t}=\left(N E R_{i, u s, t} \frac{P_{u s, t}^{T}}{P_{i, t}^{T}}\right)\left(\frac{P_{i, t}^{T}}{P_{i, t}} / \frac{P_{u s, t}^{T}}{P_{u s, t}}\right) .
$$

In this expression, the first factor denotes the bilateral real exchange rate of traded goods,

which we denote by $R E R_{i, u s, t}^{T}$. It measures deviations from the law of one price for traded goods. Notice that it also captures the effect for the real exchange rate of traded goods of any differences in the compositions of the baskets of traded goods across the two countries. The second factor is a ratio of internal relative prices, which we denote as $R E R_{i, u s, t}^{N}$. We can write 


$$
R E R_{i, u s, t}^{N}=\left(\frac{P_{i, t}^{T}}{P_{i}\left(P_{i, t}^{T}, P_{i, t}^{N}\right)}\right) /\left(\frac{P_{u s, t}^{T}}{P_{u s}\left(P_{u s, t}^{T}, P_{u s, t}^{N}\right)}\right) .
$$

Here $R E R_{i, u s, t}^{N}$ is the ratio of a function of the relative price of nontraded goods to traded goods in country $i$ to that in the United States. It is this expression that we refer to as the (bilateral) relative price of nontraded (to traded) goods.

The functional form of $R E R_{i, u s, t}^{N}$ - if we can even write it out explicitly depends on how the aggregate price indices are constructed by statisticians in each country. In the case where $P_{i}\left(P_{i, t}^{T}, P_{i, t}^{N}\right)=\left(P_{i, t}^{T}\right)^{\gamma_{i}}\left(P_{i, t}^{N}\right)^{1-\gamma_{i}}$, for example,

$$
R E R_{i, u s, t}^{N}=\left(\frac{P_{u s, t}^{N}}{P_{u s, t}^{T}}\right)^{1-\gamma_{u s}} /\left(\frac{P_{i, t}^{N}}{P_{i, t}^{T}}\right)^{1-\gamma_{i}} .
$$

In general, however, to decompose the real exchange rate into the two components $R E R_{i, u s, t}^{T}$ and $R E R_{i, u s, t}^{N}$ all we need are data on traded goods price deflators or price indices, and aggregate price deflators or price indices.

In what follows, we use equation (3), rather than equation (4), to calculate $R E R_{i, u s, t}^{N}$ and so circumvent the need to assume a functional form for aggregate price measures, or to measure the prices of nontraded goods. We now rewrite (2) as

$$
R E R_{i, u s, t}=R E R_{i, u s, t}^{T} \times R E R_{i, u s, t}^{N},
$$

which, in (natural) logarithms, is

$$
r e r_{i, u s, t}=\operatorname{rer}_{i, u s, t}^{T}+\operatorname{rer}_{i, u s, t}^{N},
$$

a simple decomposition of the real exchange rate into two components - one due to failures of the law of one price and effects due to differences in the compositions of traded goods output, and the other due to cross-country fluctuations in the relative prices of nontraded to traded goods.

It is worth pointing out that Imbs, Mumtaz, Ravn, and Rey (2002) argue that there is significant bias in constructing the aggregate price indices in (2) and (6) and that, 
furthermore, this bias is larger for traded goods sectors than it is for nontraded goods sectors.

\subsection{Summary Statistics}

To assess the relation between the bilateral real exchange rate $\operatorname{rer}_{i, u s}$ and the associated bilateral relative price of nontraded to traded goods $\operatorname{rer}_{i, u s}^{N}$, we use three different statistics. These statistics are based on the following sample moments. We denote by $\operatorname{var}\left(\operatorname{rer}_{i, u s}\right)$ the sample variance of $\operatorname{rer}_{i, u s}$,

$$
\operatorname{var}\left(\operatorname{rer}_{i, u s}\right)=\frac{\sum_{t=1}^{n}\left(\operatorname{rer}_{i, u s, t}-\overline{\operatorname{rer}}_{i, u s}\right)^{2}}{n-1}
$$

and by $\operatorname{cov}\left(\operatorname{rer}_{i, u s}, \operatorname{rer}_{i, u s}^{N}\right)$ the sample covariance between $\operatorname{rer}_{i, u s}$ and $\operatorname{rer}_{i, u s}^{N}$,

$$
\operatorname{cov}\left(\operatorname{rer}_{i, u s}, \operatorname{rer}_{i, u s}^{N}\right)=\frac{\sum_{t=1}^{n}\left(\operatorname{rer}_{i, u s, t}-\overline{\operatorname{rer}}_{i, u s}\right)\left(\operatorname{rer}_{i, u s, t}^{N}-\overline{\operatorname{rer}}_{i, u s}^{N}\right)}{n-1} .
$$

We examine three summary statistics.

1. The sample correlation,

$$
\operatorname{corr}\left(\operatorname{rer}_{i, u s}, \operatorname{rer}_{i, u s}^{N}\right)=\frac{\operatorname{cov}\left(\operatorname{rer}_{i, u s}, \operatorname{rer}_{i, u s}^{N}\right)}{\left(\operatorname{var}\left(\operatorname{rer}_{i, u s}\right) \operatorname{var}\left(\operatorname{rer}_{i, u s}^{N}\right)\right)^{1 / 2}} .
$$

2. The ratio of sample standard deviations,

$$
\frac{\operatorname{std}\left(\operatorname{rer}_{i, u s}^{N}\right)}{\operatorname{std}\left(\operatorname{rer}_{i, u s}\right)}=\left(\frac{\operatorname{var}\left(\operatorname{rer}_{i, u s}^{N}\right)}{\operatorname{var}\left(\operatorname{rer}_{i, u s}\right)}\right)^{1 / 2}
$$

3. A variance decomposition in which the covariance between the two components of the real exchange rate, $\operatorname{rer}_{i, u s}^{T}$ and $\operatorname{rer}_{i, u s}^{N}$, is allocated to fluctuations in $\operatorname{rer}_{i, u s}^{N}$ in proportion to the relative size of its variance, 


$$
\operatorname{vardec}\left(\operatorname{rer}_{i, u s}, \operatorname{rer}_{i, u s}^{N}\right)=\frac{\operatorname{var}\left(\operatorname{rer}_{i, u s}^{N}\right)}{\operatorname{var}\left(\operatorname{rer}_{i, u s}^{N}\right)+\operatorname{var}\left(\operatorname{rer}_{i, u s}^{T}\right)}
$$

We compute, but do not report here, an alternative variance decomposition measure in which half of the covariance is allocated to fluctuations in $\operatorname{rer}_{i, u s}^{N}$,

$$
\operatorname{vardec}^{2}\left(\operatorname{rer}_{i, u s}, \operatorname{rer}_{i, u s}^{N}\right)=\frac{\operatorname{var}\left(\operatorname{rer}_{i, u s}^{N}\right)+\operatorname{cov}\left(\operatorname{rer}_{i, u s}^{N}, \operatorname{rer}_{i, u s}^{T}\right)}{\operatorname{var}\left(\operatorname{rer}_{i, u s}\right)}
$$

$\left(\operatorname{Recall}\right.$ that $\operatorname{var}\left(\operatorname{rer}_{i, u s}\right)=\operatorname{var}\left(\operatorname{rer}_{i, u s}^{T}\right)+\operatorname{var}\left(\operatorname{rer}_{i, u s}^{T}\right)+2 \operatorname{cov}\left(\operatorname{rer}_{i, u s}^{T}, \operatorname{rer}_{i, u s}^{N}\right)$.) The results using this statistic are similar, but not identical, to those using statistic 3, and, for the sake of brevity, we omit them here.

We compute the above three statistics for (1) the log levels of the real exchange rate and its components, (2) the linearly detrended log levels, (3) the first log differences, and (4) the fourth log differences.

It is worth pointing out that, for the sake of simplicity, we report variance decomposition results for centered measures of variance even for data in log differences, in contrast to Rogers and Jenkins (1995) and Engel (1999), who consider mean squared error (uncentered) measures of variance of differences. To the extent to which there is a common trend in both $\operatorname{rer}_{i, u s}^{T}$ and $\operatorname{rer}_{i, u s}^{N}$, our variance decomposition will produce a lower statistic than the mean square error decomposition. For the sample of bilateral exchange rates that we consider here, however, such trends in the data are so small compared to the other fluctuations that our results do not depend on our choice of statistic in any noticeable way.

\section{DATA}

\subsection{Trade Partners}

We study the behavior of the bilateral real exchange rate of the United States with five of its trading partners: Canada, Germany, Japan, Korea and Mexico. Our choice of this set of U.S. trade partners is governed by two considerations. First, for each of these countries there are three alternative measures for rer $_{i, u s}$ and four related alternative 
measures for $\operatorname{rer}_{i, u s}^{N}$ for the sample 1980-2000, subject to very few missing observations. (Lack of data forces us to omit from the sample the People's Republic of China, including Hong Kong, and the United Kingdom, the United States' fourth and fifth largest trade partners in 2000.) Second, although these five countries account for more than half of U.S. trade in 2000, they represent a broad cross-section of trade partners by the importance of their trade relationship with the United States. For the two largest U.S. trade partners - its two North American Free Trade Area partners, Canada and Mexico - each of their bilateral trade relationships with the United States represents a large fraction both of GDP and of total trade. The size of their bilateral trade relationship with the United States is less important for Japan and Korea, and it is relatively trivial for Germany.

The computed values of the statistics which we use to measure the size of the trade relationship between the United States and each trade partner are presented in Table 5. Here, the bilateral trade of country $i$ with the United States is measured as the sum of f.o.b. exports from country $i$ to the United States and the f.o.b. exports of the United States to country $i$, both measured in U.S. dollars. Both total trade and GDP are also measured in U.S. dollars. All trade data are from International Monetary Fund data sources, as documented in Appendix B.

\subsection{Real Exchange Rates}

We need three data series to construct any U.S. bilateral real exchange rate: (1) a nominal exchange rate series between the United States and trade partner $i,(2)$ an aggregate price level measure for the United States, and (3) a comparable aggregate price level measure for country $i$. All five bilateral nominal exchange rate series are drawn from the International Monetary Fund's International Financial Statistics. For each bilateral trade relationship, we use three different measures of the aggregate price level in a country: (1) the $G O$ deflator, (2) the $C P I$, and (3) the PCD. Results using the Gross Domestic Product (GDP) deflator are discussed in Appendix A.

The $G O$ deflator is computed as the ratio of nominal gross output summed over all sectors to real gross output summed over all sectors. The underlying gross output data by sector are available only at the annual frequency for the countries in our sample. It is 
worth pointing out that it is relatively difficult to find $G O$ data for a large number of countries. It is the availability of sectoral $G O$ data that is the limiting factor in our choice of trade partners. Gross output data are found typically in the publications of national statistical agencies that are responsible for computing the input-output matrices for a country. Details on our sources can be found in Appendix B.

The CPI is a (non-geometric) base-year quantity weighted average of the prices of a basket of goods and services consumed within a country - a Laspeyres price index. This is a very different price measure on both conceptual and practical grounds from the $G O$ deflator. As a consumption-based aggregate price measure, it measures the price of a basket of goods and services consumed in a country, rather than measuring a price of the goods and services produced in a country as does the $G O$ deflator. The $C P I$ for a country includes the prices of (traded) imported goods. It also includes the prices of nontraded wholesale, distribution and retail services that are embodied in the final consumer prices of otherwise traded goods. We measure the CPI for country $i$ at date $t$ as

$$
C P I_{i t}=\sum_{j} \alpha_{i j} p_{i j t}^{C}
$$

where $p_{i j t}^{C}$ is the price paid for good or service $j$ by consumers in country $i$ at date $t$ and $\alpha_{i j}$ is a base-period expenditure weight on good $j$. The primary advantage of using the $C P I$ is that it is readily available for all of the countries in our sample at the monthly, quarterly, and annual frequencies.

Finally, the $P C D$ is computed as the ratio of nominal personal consumption expenditure to real personal consumption expenditure, where personal consumption expenditure is defined as in the national income and product accounts. Like the $C P I$, the $P C D$ measures the price of a consumption basket of goods and services, rather than measuring a price of the goods and services produced by a country. Notice that it is a deflator, unlike the $C P I$, which is a fixed weight price index.

Once we have collected each of these three aggregate price series for the United States and its five trade partners, we can construct three alternative measures of the (log) bilateral U.S. real exchange rate $-r e r_{i, u s}$ - for each trade partner, $i$. One question that arises is, Do the measured aggregate real exchange rates that we compute for any country 
$i$ behave differently according to which aggregate price series we use to construct them?

In fact, the aggregate real exchange rates based on the different price series are extremely highly correlated with each other, but — at least in some cases — exhibit different volatilities. We do not explore the implications of these volatility differences here, but leave them for future research.

\subsection{Traded Goods Price Measures}

We must also compute a measure of bilateral relative price of nontraded to traded goods $\mathrm{rer}_{i, u s}^{N}$ for each bilateral trade relationship. To do this, we need a measure of the price of traded goods, $P_{i}^{T}$, to compute $\operatorname{rer}_{i, u s}^{N}$. We develop four alternative measures for each country: (1) the $G O$ deflator for relatively traded goods sectors, (2) the PPI, (3) the $C P I$ for all goods (but excluding all services), and (4) the $P C D$ for all goods.

To construct the $G O$ deflator for traded goods sectors, we start by defining traded goods. We follow a common convention of classifying agriculture, mining and petroleum, and manufacturing as traded. This leaves services, utilities, and construction as nontraded. We sum the values of nominal gross output over all relatively traded goods sectors and divide the result by the sum of values of real gross output over all relatively traded goods sectors to generate $P_{i}^{T}$ for any trade partner $i$ - a traded goods price deflator. We finally calculate $\operatorname{rer}_{i, u s}^{N}$ by taking the logarithm of (3). An alternative convention for classifying goods would disaggregate services and include transportation services as a traded goods category. In calculations not reported here, we find that following this alternative convention does not have a significant impact on our results.

It is worth noting that we could have used the same classification of traded goods to construct a measure of the price of traded goods $P_{i}^{T}$ using data on GDP by sector. Here, we would sum over the nominal value added of each relatively traded goods sector to form the numerator, and sum over the real value added of each relatively traded goods sector to form the denominator of the traded goods price deflator. Nevertheless, although the aggregate $G D P$ deflator and the aggregate $G O$ deflator are conceptually similar objects - differing only in the weights assigned to different prices - a sectoral GDP deflator is conceptually a very different object from the corresponding sectoral $G O$ 
deflator. While the sectoral $G O$ deflator is a measure of the prices of goods sold by that sector, the corresponding sectoral GDP deflator subtracts out weighted sums of prices of intermediate inputs purchased from other sectors. This means that the $P_{i}^{T}$ that one could construct as we describe here using sectoral GDP deflators is not the price of traded good sectors' output per se, but a measure of the value of a subset of inputs into the output of those sectors. Here, we do not report results based on GDP deflators due to this conceptual problem, but discuss them further in Appendix A.

The PPI for country $i$ is the second measure of the price of traded goods that we use. This index is a base-year-output weighted average of the prices of goods charged by producers at the site of production. It can be written as

$$
P P I_{i t}=\sum_{j} \beta_{i j} p_{i j t}^{P}
$$

where $p_{i j t}^{P}$ is the price charged by producers in country $i$ for good $j$ at date $t$ and $\beta_{i j}$ is a base period production weight on good $j$. The data used to construct the graphs in Figure 1 use monthly CPI as the series of aggregate price levels and monthly PPI as the series of traded goods price levels.

The third measure of the traded goods price level is the CPI for all goods (which excludes the prices of all services). For country $i$, this measure is

$$
C P I_{i t}^{G}=\frac{\sum_{j \in G} \alpha_{i j} p_{i j t}^{C}}{\sum_{j \in G} \alpha_{i j}}
$$

where $G$ is the subset of all goods and services that are goods, specifically the category all goods except food in CPI data.

Our fourth and final measure of the price index for traded goods is the $P C D$ for commodities. This is computed as the ratio of nominal to real consumption expenditures on commodities.

\subsection{Discussion}

On conceptual grounds, we prefer to use $G O$ deflators by sector to construct traded goods price measures. These deflators measure the prices of output by sector at the production site. They are the prices charged by producers to wholesalers, distributors, 
and retailers. They are, therefore, exclusive of the prices of any nontraded wholesale, distribution, and retail services that are included in the prices charged to final consumers. If the goal is to capture prices of traded goods - goods for which arbitrage can successfully eliminate individual price differentials, as in the traditional theory, or reduce these differentials below those for less tradable goods, as in the modified theory of Betts and Kehoe (2004b) - then production based prices are preferable to consumption based prices. Unfortunately, data on $G O$ by sector are only available for a small subset of countries, and only at the annual frequency. It is worth pointing out, however, that national statistical agencies typically derive constant price values for gross output using detailed production site price data collected by the same agencies that construct PPIs, often in the same surveys.

Our next conceptually preferred, and most broadly available, measure of an aggregate traded goods price for a country is, therefore, its PPI for all goods. While there are inevitably some goods in this index that are not traded very much, as noted by Engel (1999), this will be true of any other measure as well. It is particularly true of measures based on consumption data that include nontraded wholesale, distribution, and retail services. As with gross output data, the individual prices that are used to construct the PPI are measured at the production site and hence exclude the value of these services. In addition, the prices of the items in the producer basket of goods are final output prices at the production site rather than the value added of the sector (as is true of GDP deflators).

Nonetheless, using the PPI-CPI ratio to calculate $R E R_{i, u s}^{N}$ suffers from the criticism that the two data series required in its construction are drawn from different data surveys. This problem is discussed in detail by Engel (1999). This is not true of any other measures of this relative price that we consider. For example, $G O$ deflators for relatively traded goods sectors and aggregate $G O$ deflators are drawn from the same survey, as are $P C D$ s, and aggregate and sectoral CPIs. There are three implications of this fact that are relevant:

1. The weights in the $C P I, \alpha_{i j}$ in (10), are based on historical consumption values, while the weights applied in the $P P I, \beta_{i j}$ in $(11)$, are based on historical production values 
in a country. Consequently, even if all goods in the world economy are perfectly tradable, with prices that obey the law of one price, measured bilateral real exchange rates need not exhibit purchasing power parity. This is because the ratio of the CPI to the PPI need not be unity either within or across countries. In addition, relative consumption and production weights can vary over time due to a different timing of weight updating.

2. As noted by Engel (1999), when $C P I$ and PPI data are used to construct $r e r_{i, u s}^{N}$ and $\mathrm{rer}_{i, u s}^{T}$, the components may be negatively correlated due to the fact that the international ratio of traded goods' prices appears in both components but in opposite ways. This is not in itself a substantive problem for the analysis here, however; we compute directly the covariance of $r e r_{i, u s}^{N}$ and $r e_{i, u s}^{T}$ in constructing our variance decomposition statistic.

3. The $C P I$ and the $P P I$ may record different prices for the same traded good because they survey different locations. Within country price differences should be of considerably smaller magnitude than international price differences, however, as has been shown by Engel and Rogers (1996). In addition, there is no a priori reason to believe that cross-survey traded good price differences vary systematically by location thereby imparting a bias in the value of $\operatorname{rer}_{i, u s}^{N}$ and $\operatorname{rer}_{i, u s}^{T}$. Cross-survey price differentials may be time varying, however, due to changes in survey location, and such variation can cause measured variation in $\mathrm{rer}_{i, u s}^{N}$. Such variation is probably very infrequent, however.

\section{RESULTS}

The results of our analysis are presented in Figures 2-3, and in Tables 1-5. Country specific results are presented in Figures 3A-3E, in Table 1, in Tables 2A-2E, and in Table 4. Trade weighted results, which summarize how the values of the statistics vary across price series, are presented in Tables 3 and 4 . Table 5 presents results on how 
the statistics vary across countries, using our conceptually preferred measure of traded goods prices based on $G O$ deflators by sector.

In the results, we consider the relation between the real exchange rate and relative price of nontraded goods for each of the following sets of measures: the $G O$ based aggregate real exchange rate and the measure of $\operatorname{rer}_{i, u s}^{N}$ based on ratios of the aggregate $G O$ deflator to the $G O$ deflator by sector; the $C P I$ based real exchange rate and the measure of $\operatorname{rer}_{i, u s}^{N}$ based on ratios of the PPI to the CPI; the CPI based real exchange rate and the measure of $\operatorname{rer}_{i, u s}^{N}$ based on ratios of the aggregate $C P I$ to the $C P I$ for all goods excepts food; and the PCD based aggregate real exchange rate and the measure of $\operatorname{rer}_{i, u s}^{N}$ based on ratios of the aggregate $P C D$ to the $P C D$ for all commodities. Of course, we compute the values of the summary statistics for all four of these pairs of measures for every trade partner-U.S. pairing.

We compute the values of our summary statistics for all trade pairings and for all sets of price measures for the data measured in $(\log )$ levels, in linearly detrended $(\log )$ levels, in one year $(\log )$ changes, and in four year $(\log )$ changes. Considering all of these transformations of the data circumvents the need for us to make any assumption on whether there are "trends" or permanent components in the real exchange rate and relative price measures when our simple analytical framework does not provide for such an assumption. It also allows us to directly compare the statistical properties across alternative data transformations.

\subsection{Frequency Does Not Matter}

Figure 2 and Table 1 illustrate a general result that frequency does not matter for the values of the statistics, at least for the case of $C P I$ and PPI data where we have data at monthly, quarterly, and annual frequencies. Table 1 presents values of the three statistics that summarize the relationship between the bilateral real exchange rate and relative price of nontraded to traded goods for the Canada-U.S. case. Here CPIs are used to measure aggregate prices and PPIs are used to measure the prices of traded goods. The same sorts of results obtain for the unreported cases of all other bilateral U.S. pairings with trade 
partners using the same price data. Figure 2 presents the data for the Canada-U.S. case graphically, plotting $\operatorname{rer}_{i, u s}$ and $\operatorname{rer}_{i, u s}^{N}$ for monthly, quarterly, and annual data.

The figure shows that directional movements of $\operatorname{rer}_{i, u s}$ and $\operatorname{rer}_{i, u s}^{N}$ are very similar, and that $\operatorname{rer}_{i, u s}^{N}$ is less volatile than $\operatorname{rer}_{i, u s}$. These features appear to be independent of the frequency of the data, and Table 1 confirms this. In the first three rows of Table 1 , we see that the values of $\operatorname{corr}\left(\operatorname{rer}_{i, u s}, \operatorname{rer}_{i, u s}^{N}\right), \operatorname{std}\left(\operatorname{rer}_{i, u s}^{N}\right) / \operatorname{std}\left(\operatorname{rer}_{i, u s}\right)$, and $\operatorname{vardec}\left(\operatorname{rer}_{i, u s}, \operatorname{rer}_{i, u s}^{N}\right)$ are, for all practical matters, identical across frequencies when we examine the data in levels. The second three rows of Table 1 demonstrate that this is also true when we examine the data in linearly detrended levels. In the final three rows of Table 1, we examine the behavior of the data in changes. Comparing values of the statistics for the annual data at the first lag to those of the quarterly data at the fourth lag and to those of the monthly data at the twelfth lag, we see that they are essentially identical across these three series. The values of the statistics are also essentially identical when we compare the values for the quarterly data at the first lag to those of the monthly data at the third lag and when we compare the annual data at the fourth lag to those of the quarterly data at the sixteenth lag and to those of monthly data at the fortyeighth lag. The frequency of the data - monthly, quarterly, or yearly — does not matter for the value of the statistics. This is not to say that the length of the lag does not matter: The correlations between $\operatorname{rer}_{i, u s}$ and $\operatorname{rer}_{i, u s}^{N}$ based on four year changes in data (4 lags in annual data, 16 lags in quarterly data, 48 lags in monthly data), for example, are higher than those based on one year changes, which, in turn, are higher than those based on one quarter changes, which, in turn, are higher than those based on one month changes.

These features of the Canada-U.S. data illustrate a general result that holds across countries: the frequency of the data is irrelevant for the values of our statistics. We therefore focus on the properties of the annual data - the frequency at which we have data for all four measures of the relative price of nontraded goods — in our analysis from this point on. We report the statistics for both four year changes and one year changes. The limitation of using annual data, of course, is that we cannot report monthly or quarterly changes. 


\subsection{Detrending Matters}

The results presented in Table 1 also suggest — at least for the Canada-U.S. case — that whether we detrend the data or not, or whether we study the data in levels or those in yearly or higher changes, does have an impact on the values of the statistics. Table $2 \mathrm{~A}$ confirms this. The second column of Table 2A shows that, when we use annual CPI and PPI data to construct the two variables $\operatorname{rer}_{i, u s}$ and $\operatorname{rer}_{i, u s}^{N}$, the correlation between these two variables declines as we move from considering the data measured as levels to the data measured as linearly detrended levels to the data measured as one year changes. The correlation is much higher, however, for the data measured in four year changes than it is for one year changes. By contrast, the ratio of standard deviations of the two variables is relatively stable across levels, linearly detrended levels, one year changes, and four year changes. The variance decomposition statistic declines from 0.52 for the data measured as levels to 0.45 for the data measured as detrended levels to 0.36 for the data measured as one year changes. For the data measured as four year changes, there is an increase in the value of the variance decomposition statistic to 0.44 , relative to the case of one year changes.

Figures $3 \mathrm{~A}$ shows that that there is a positive trend (depreciation) in the bilateral Canada-U.S. real exchange rate over our sample period. One point of view is that this sort of trend is something that a model of the real exchange rate should be able to account for, making the data measured as non-detrended levels more interesting to study than the data measured as detrended levels. Another possibility, suggested by Burnstein, Eichenbaum, and Rebelo (2002), is that there are systematic differences across countries in the way that price indices are constructed that may give rise to trends. This is obviously a topic that merits more study and which is beyond the scope of the current paper.

We assess whether detrending matters for the values of the statistics for the remaining four bilateral trade relationships, examining the values of the statistics for the same annual CPI and PPI data in the second column of data in Tables $2 \mathrm{~B}-2 \mathrm{E}$. These statistics show that there are typically differences across alternative transformations of the data in, at least, the values of the correlation and variance decomposition statistics. It 
is interesting, however, that there is no systematic cross-country pattern of these differences.

In the Germany-U.S. case, for example, in contrast to the Canada-U.S. case, the correlation between $\operatorname{rer}_{i, u s}$ and $\operatorname{rer}_{i, u s}^{N}$ is lowest for the data measured as levels, rising as we examine the data measured as detrended levels and the data measured in one year changes, and finally falling somewhat when we examine the data measured as four year changes. In the Japan-U.S. case, the pattern of values of correlations across alternative transformations of the data mirrors that for the Canada-U.S. case. The pattern for KoreaU.S. in Table 2D is different; here, the correlation, relative standard deviation and variance decomposition statistic values are very similar for the linearly detrended data relative to the data measured as one year or, especially, four year changes. In addition, the value of the correlation statistic for the data in levels is substantially lower than that for the detrended data, while that of the relative standard deviation statistic is much higher. Finally, the pattern of changes in the values of the statistics in the Mexico-U.S. data mirror that observed in the Canada-U.S. and Japan-U.S. data.

In short, we find two results: (1) whether and how one detrends real exchange rate and relative price data matters for the value of the summary statistics that we employ, and (2) the specific manner in which the values of the statistics vary across alternative transformations of the data depends on which bilateral real exchange rate and relative price of nontraded goods is used. Consequently, we argue that whether and how one detrends a bilateral real exchange rate should be determined by economic theory. In particular, the detrending approach applied to the data should be consistent with the specific model that is being used to account for real exchange rate movements.

\subsection{Price Series Matter}

We next ask, Do our results depend on the price series used in an important way? Results presented in Engel (1999) suggest that the values of some key statistics may be different depending on which price series are used to measure aggregate and sectoral price levels. Table 3 presents values of the three summary statistics for each of the four sets of price series that are averaged across countries. Specifically, the average value of each statistic is computed as the weighted average of the five trade partner-specific 
values of that statistic where the weights are given by the volume of bilateral trade relative to total U.S. trade. These trade-weighted average values of the statistics permit a focus on how the behavior of the statistics depends on which set of price series is used to construct $\operatorname{rer}_{i, u s}$ and $\operatorname{rer}_{i, u s}^{N}$ by suppressing country specific detail.

Consider the first three rows in Table 3. These present the values of statistics 1-3 for the data measured in levels. The first row examines correlations between rer $_{i, u s}$ and $\operatorname{rer}_{i, u s}^{N}$ for each of the four alternative sets of price series. The value of the correlation is always positive, and it ranges from a minimum of 0.14 when $C P I$ component and $C P I$ data are used to construct $r e r_{i, u s}^{N}$ to 0.71 when PPI and CPI data are used. It is notable that the lowest correlation values are found for the two cases in which consumer price data are used to construct $P_{i}^{T}$. The highest values are obtained when the data on sectoral $G O$ deflators and the PPI data are used to construct $P_{i}^{T}$.

The values of the relative standard deviation of $\operatorname{rer}_{i, u s}^{N}, \operatorname{std}\left(\operatorname{rer}_{i, u s}^{N}\right) / \operatorname{std}\left(\operatorname{rer}_{i, u s}\right)$, are presented in the second row of data for the data measured as levels. The value of this statistic is more consistent across sets of price data than is the correlation- it ranges from a minimum of 0.36 when the ratio $P C D$ for commodities $P C D$ measures rer $_{i, u s}^{N}$ to a maximum of 0.42 when the ratio CPI for goods/CPI measures $\operatorname{rer}_{i, u s}^{N}$.

The values of the variance decomposition statistic are also more consistent across alternative price series than are those of the correlation. It is worth noting that, again, the lowest values of the variance decomposition statistics are observed when consumption based data are used to construct $P_{i}^{T}$ and $\operatorname{rer}_{i, u s}^{N}$. The value of the variance decomposition statistic is highest when PPI or sectoral $G O$ data measure $P_{i}^{T}$ and lowest when $C P I$ or PCD component data do so.

We next examine the values of the statistics when the logged data are linearly detrended, in the second three rows of data in Table 3, when the data are measured as one year changes, in the third three rows of Table 3, and when the data are measured as four year changes in the fourth set of three rows of data in the table. Again there are large differences across price series in the measures of $\operatorname{corr}\left(\operatorname{rer}_{i, u s}, \operatorname{rer}_{i, u s}^{N}\right)$ for all of these 
transformations of the data. Notably, the cross-price series ranking of the magnitude of this correlation is identical to that in the non-detrended levels. Once again, the largest correlations between the bilateral real exchange rate and the associated bilateral relative price of nontraded to traded goods are observed when the production based price data are used to construct $P_{i}^{T}$ - the $G O$ and PPI measures - while the lowest values are observed when consumption based - $-C P I$ and $P C D$ component - data are used.

The value of the relative standard deviation of $\operatorname{rer}_{i, u s}^{N}$ is less stable across price series in the detrended relative to the non-detrended data, however. It is also worth noting that the value of the relative standard deviation declines systematically for all alternative price series compared to its value with the non-detrended data. The values of the variance decomposition statistics tend to be lower in the linearly detrended data relative to the data in levels, and the cross-price variation in the values of the variance decomposition statistics is higher. Once again, the value of the variance decomposition statistic is highest when PPI or sectoral $G O$ data measure $P_{i}^{T}$ and lowest when $C P I$ or $P C D$ component data do so. Notice that the values of all three summary statistics computed when we use $G O$ data are similar to the values computed when we use PPICPI data.

The third and fourth sets of three rows of data in Table 3 show the trade-weighted values of the statistics for the data in one year changes and four year changes, respectively. These two sets of rows of statistics show similar patterns. The statistics for the data in four year changes tend to be higher than those for the data in one year changes. Notice that the values of all three of our summary statistics are higher - both for the data in one year changes and for the data in four year changes - when PPI or sectoral $G O$ data are used to measure $P_{i}^{T}$ than they are when $C P I$ or $P C D$ component data is used do so. Once again, for both data in one year changes and data in four year changes, all three statistics are similar to the values for the price series based on $G O$ and PPI-CPI data. 


\subsection{Choice of Trade Partner Matters}

We now examine whether and to what extent the computed values of the statistics in the trade-weighted data are representative of all five bilateral U.S. real exchange rates in the sample. Consider first the values of the summary statistics for alternative measures of $r e r_{i, u s}$ and $r e r_{i, u s}^{N}$ for the Canada-U.S. case in Figure 3A and Table 2A. It is not surprising that the values of these statistics largely mirror those observed in the tradeweighted data, given the large fraction of U.S. trade accounted for by the bilateral Canada-U.S. relationship. Notice, however, that the Canada-U.S. statistics convey a stronger impression that there exists a very important relationship between the real exchange rate and the relative price of nontraded goods.

For example, we notice that the highest values of the correlation statistics are found when we use $G O$ or $P P I$ data to measure the price of traded goods, and the lowest are found when we use consumption based measures based on $C P I$ component or $P C D$ component data. In fact, the values of the correlation statistic for the consumption based price measures are actually negative in linearly detrended and one year change data. As in the trade-weighted averages, the values of the correlation statistic are very similar when prices are measured using $G O$ and $P P I-C P I$ and also very similar when prices are measured using $C P I$ and $P C D$ data. This result does not depend on whether or how the data are detrended. Once more, $G O$ and $P P I-C P I$ based price measures behave very similarly for all the statistics across data transformations, as do the $C P I$ and $P C D$ based measures. Overall, Table 2A shows statistic values that are higher than those in the trade-weighted data, suggesting that there exists a relatively strong relationship between $\mathrm{rer}_{i, u s}$ and $r e r_{i, u s}^{N}$ for the Canada-U.S. real exchange rate.

The pattern of results observed in the Mexico-U.S. data in Figure 3E and Table $2 \mathrm{E}$ is similar to that in the Canada-U.S. data. Here, however, all computed values of the correlation between $\mathrm{rer}_{i, u s}$ and $\mathrm{rer}_{i, u s}^{N}$ are high and positive, across different measures of prices and irrespective of whether and how we detrend. In fact, the computed values of all statistics are relatively high and stable across price measures and data transformations. There is a noticeable decline, however, in the computed values of all statistics for all alternative price measures for data in one year changes relative to those for the levels and 
detrended levels. In contrast, the statistics for data in four year changes tend to be even higher than those for data in levels and detrended levels. Overall, the statistics for both the Canada-U.S. and the Mexico-U.S. cases suggest that there is an important relationship between the real exchange rate and the relative price of nontraded goods.

We next examine the results for the Germany-U.S. real exchange rate in Figure 3B and Table 2B. These contrast dramatically with those for Canada-U.S. and MexicoU.S. What jumps out of the table is the large number of low and negative values for the $\operatorname{corr}\left(r e r_{i, u s}, \operatorname{rer}_{i, u s}^{N}\right)$ and for the $\operatorname{vardec}\left(r e r_{i, u s}, \operatorname{rer}_{i, u s}^{N}\right)$ statistics and of low values for the relative standard deviation statistics. Notice that the values of the relative standard deviation and variance decomposition statistics are relatively similar in the cases when $G O$ and $P P I$ data are used to construct $P_{i}^{T}$, especially when we consider the linearly detrended and one year change data. More generally, there is much less variation across alternative price measures than in either Tables $2 \mathrm{~A}$ and $2 \mathrm{E}$ or in the trade-weighted data presented in Table 3. While the Mexico-U.S. case is characterized by consistently relatively high values of the summary statistics, the Germany-U.S. case is characterized by consistently low values of the summary statistics. Here, there is little evidence of a strong role for the relative price of nontraded goods in real exchange rate determination.

Similar statements can be made regarding the results for the Japan-U.S. real exchange rate and relative price results in Table 2C. Here too there is little evidence to support an important role for the relative price of nontraded goods in real exchange rate determination. As in the Germany-U.S. case, there are a large number of comparatively small and even negative values of the statistics. Variation across alternative price measures is relatively limited, and there is a marked similarity in the values of the statistics for the $G O$ and $P P I$ based price measures.

Finally, in Table 2D, we examine the results for the Korea-U.S. real exchange rate. This set of results is unlike any other seen in Table 2. In fact, the results for Korea seem to most closely reflect those of the trade-weighted data. All correlations are fairly high and positive, but particularly so in the detrended and differenced data. The relative standard deviation statistic is high when the data are not detrended, ranging from 0.26 to 0.60 , but are also substantively different from zero in detrended and differenced data. By contrast, most of the variance decomposition results show a relatively small role for 
$\operatorname{rer}_{i, u s}^{N}$ in accounting for total real exchange rate variance. There is fairly high variation across alternative price measures here and, once more, the computed values of the statistics tend to be similar when $G O$ by sector and PPI data measure the price of traded goods.

We now examine the results in Table 4. Here we compute the simple correlation between two alternative measures of $\operatorname{rer}_{i, u s}^{N}$ for four of the eight possible sets of pairs of measures. We focus on comparisons with our conceptually preferred $G O$ measure. Specifically, we compute the simple correlation between the $G O$ and PPI-CPI measures of $\operatorname{rer}_{i, u s}^{N}$; between the $G O$ and $C P I$ component measures; between the $G O$ and $P C D$ component measures; and between the $C P I$ component and $P C D$ component measures. We compute the correlations for each country and then construct a trade-weighted average correlation, which is presented in the final column of the table.

We note that the final column of Table 4 shows that the most highly correlated measures of $\operatorname{rer}_{i, u s}^{N}$ are those based on CPI component and PCD component data. The next most highly correlated are the two measures based on GO and PPI-CPI data. These results partially reflect earlier findings regarding the similarity of computed values of the three summary statistics in the country-specific and trade weighted data when these particular sets of price data are compared. The final column in Table 4 also shows that, at least when the price data are linearly detrended or differenced, there are relatively low computed correlations between the $G O$ based measure of $\operatorname{rer}_{i, u s}^{N}$ and those constructed using either $C P I$ or $P C D$ component data. Again, this reflects the fact that the degree of similarity in computed values of the summary statistics for the latter two measures of $\operatorname{rer}_{i, u s}^{N}$ are dissimilar to those for the former measure, as shown in many of the countryspecific results of Table 2 .

Looking down the fifth column of correlation values in Table 4, we see that the Mexico-U.S. data are characterized by systematically high and positive computed correlations between alternative measures of $\operatorname{rer}_{i, u s}^{N}$. This, we argue, is reflected in the Mexico-U.S. results presented in Table 2E, where all computed values of the summary statistics are positive and relatively high. There is comparatively little cross-price 
variation in the Mexican data. The same is broadly true of the Canada-U.S. correlations, presented in the first column of data. Here, however, the correlation between the $G O$ and consumption based measures of $\operatorname{rer}_{i, u s}^{N}$ are all low, and actually negative when the data are detrended or differenced. The Germany-U.S. correlation results in the second column of Table 4, and also those for Japan-U.S. data in the third column, are generally high and positive. In the Germany-U.S. case, all correlations computed between alternative measures of $\operatorname{rer}_{i, u s}^{N}$ are high and positive, although not as large as those computed for the Mexico-U.S. data. In the Japan-U.S. case, there is more variation in the values of the correlation between alternative measures of $\operatorname{rer}_{i, u s}^{N}$ when we examine the levels of the data, in particular, and in general the correlation values are lower than those for Mexico overall. In the correlations for the Korea-U.S. measures of $\operatorname{rer}_{i, u s}^{N}$, there are actually three negative values when we examine the levels of the data. Much higher values of the correlations across alternative measures emerge when the data are detrended either linearly or by taking differences, however.

Table 4 shows that there are some significant differences across trade partners in the computed correlations between alternative measures of $\operatorname{rer}_{i, u s}^{N}$. In other words, some of the cross-country variation in statistics that summarize the relationship between the real exchange rate and relative price of nontraded goods identified in Table 2 can be attributable to cross-country differences in the prices used to measure these two variables. These differences are relatively small, however, when we limit ourselves to considering the three largest trade partners of the United States - Canada, Mexico, and Japan. The trade-weighted average of correlations is reasonably representative of the relationships between alternative measures of $\operatorname{rer}_{i, u s}^{N}$.

\section{CONCLUSION}

In this paper, we have identified several key facts in our data on U.S. real exchange rates and relative prices: 
Fact 1. The frequency of the data does not significantly affect statistical measures of the relationship between the real exchange rate and the relative price of nontraded goods.

Fact 2. Whether and how we detrend real exchange rate and relative price data significantly affects statistical measures of the relationship between the real exchange rate and the relative price of nontraded goods.

Fact 3. Which price series are used to measure the prices of traded goods and to construct the relative price of nontraded goods significantly affects statistical measures of the relationship between the real exchange rate and the relative price of nontraded goods.

Fact 4. The choice of bilateral U.S. trade partner significantly affects statistical measures of the relationship between the real exchange rate and the relative price of nontraded goods.

In regard to Fact 3, when production based prices such as the $G O$ deflator for traded goods or the $P P I$ are used to measure $P_{i}^{T}$, we find that correlations, standard deviations, and variance decomposition values tend to be high, implying that movements in the relative price of nontraded goods are relatively closely related to real exchange rate fluctuations. By contrast, when consumption based prices are used to measure $P_{i}^{T}$, the values of all of our summary statistics tend to be low. We have argued in Section 3 that thinking about the concept of traded goods in terms of arbitrage possibilities leads us to prefer on conceptual grounds price measures based on producer prices to price measures based on consumer prices. Measures based on consumer prices may be preferred, of course, in other work, if there is no emphasis - as there is here - on measuring prices of traded goods that can reasonably be argued to be subject to arbitrage.

In regard to Fact 4, we have shown that one part of the explanation for the differences in results across U.S. trade partners lies in cross-country differences in the price series used to construct the real exchange rate and relative price of nontraded goods. 
In Table 5, we suggest that a more important factor may be the intensity of trade between the United States and that trade partner.

Table 5 shows a positive relationship in our data between measures of the importance of trade between the United States and a trade partner, and measures of the strength of the relationship between the real exchange rate and its relative price of nontraded goods component. Here we restrict the analysis to the aggregate $G O$ deflator real exchange rate and to the sectoral $G O$ deflator measure of $\operatorname{rer}_{i, u s}^{N}$. The table shows that the higher are the measures of trade intensity presented for each U.S. trade partner in the first three rows of data, the higher are the values of our three summary statistics. CanadaU.S. trade is very important to Canada (and also important to the Unites States, as illustrated in the second set of three rows of data in Table 5). The values of the summary statistics for Canada are systematically higher than those for any other country. MexicoU.S. trade ranks second by our criteria, and the values of summary statistics for Mexico are somewhat lower than for Canada but nonetheless are generally high and always positive. Germany exhibits the least important trade relationship with the United States, and the values of all summary statistics are low — and sometimes negative. Japan and Korea are intermediate cases. Overall, when the size of the trade relationship between the United States and a trade partner is large for at least one of the two countries, the more closely related are real exchange rate movements and fluctuations in the relative price of nontraded goods.

That variance decompositions show a relatively important role for the relative price of nontraded goods in accounting for real exchange rate variance for the most important U.S. trade partners is especially interesting. It suggests that the larger are trade flows between two countries, the lower is the relevance for real exchange rate fluctuations of deviations from the law of one price for the goods that are being most heavily traded. More specifically, the results imply that the degree to which one country's goods are actually traded with respect to another specific country, the stronger is the predictive content of the traditional theory. Betts and Kehoe (2004a) explore and verify this empirical relationship for a much larger set of bilateral trade relations using widely available $C P I$ and $P P I$ data. 


\section{REFERENCES}

Balassa, B. (1961), "Patterns of Industrial Growth," American Economic Review, 51, 394-397.

Balassa, B. (1964), “The Purchasing Power Parity Doctrine: A Reappraisal,” Journal of Political Economy, 72, 584-596.

Betts, C. M. and T. J. Kehoe (2004a), "Real Exchange Rate Movements and the Relative Price of Nontraded Goods," University of Minnesota and University of Southern California.

Betts, C. M. and T. J. Kehoe (2004b), “Tradability of Goods and Real Exchange Rate Fluctuations," University of Minnesota and University of Southern California.

Burnstein, A., M. Eichenbaum and S. Rebelo (2002), "Why is Inflation So Low after Large Devaluations?” NBER Working Paper 8748.

Cassel, G. (1918), “Abnormal Deviations in International Exchanges,” Economic Journal, 28, 413-415.

Chari, V. V., P. J. Kehoe, and E. R. McGrattan (2002), "Can Sticky Price Models Generate Volatile and Persistent Real Exchange Rates?" Review of Economic Studies, 69, 533-563.

Crucini, M. J., C. I. Telmer, and M. Zachariadis (2001), "Understanding European Real Exchange Rates, Vanderbilt University.

Engel, C. (1993), "Real Exchange Rates and Relative Prices - An Empirical Investigation," Journal of Monetary Economics, 32, 35-50.

Engel, C. (1999), “Accounting for U.S. Real Exchange Rate Changes,” Journal of Political Economy, 107, 507-538.

Engel, C. and J.H. Rogers (1996), "How Wide is the Border?" American Economic Review, 86, 1112-1125.

Fernández de Córdoba, G. and T. J. Kehoe (2000), “Capital Flows and Real Exchange Rate Fluctuations Following Spain's Entry into the European Community," Journal of International Economics, 51, 49-78.

Imbs, J., H. Mumtaz, M. O. Ravn, and H. Rey (2002), "PPP Strikes Back: Aggregation and the Real Exchange Rate," NBER Working Paper 9372.

Knetter, M. (1997), "International Comparisons of Pricing-to-Market Behavior," American Economic Review, 83, 473-486. 
Kravis, I.B. and R.E. Lipsey (1978), "Price Behavior in Light of Balance of Payments Theories," Journal of International Economics, 8, 193-246.

Lapham, B.J. (1995), “A Dynamic General Equilibrium Analysis of Deviations from the Law of One Price," Journal of Economic Dynamics and Control, 19, 1355-1389.

Obstfeld, M. (2001), "International Macroeconomics: Beyond the Mundell-Fleming Model," IMF Staff Papers, 47, special issue, 1-39.

Pigou, A. (1923), “The Foreign Exchanges,” Quarterly Journal of Economics, 37, 52-74.

Rebelo, S. and C. A. Vegh (1995), "Real Effects of Exchange Rate-Based Stabilization: An Analysis of Competing Theories," in B. S. Bernanke and J. J. Rotemberg, editors, NBER Macroeconomics Annual 1995. The MIT Press, 125-174.

Rogers, J. H. and M. Jenkins (1995), "Haircuts or Hysteresis? Sources of Movements in Real Exchange Rates,” Journal of International Economics, 38, 339-360.

Samuelson, P. A. (1964), “Theoretical Notes on Trade Problems," Review of Economics and Statistics, 46, 147-154.

Stockman, A. C. and L. L. Tesar (1995), "Tastes and Technology in a Two-Country Model of the Business Cycle: Explaining International Comovements," American Economic Review, 85, 168-185. 


\section{APPENDIX A}

As we note in Section 3.3, this paper studies the relationship between real exchange rates and relative prices of nontraded goods using output based price measures that are based on gross output data rather than those that are based on gross domestic product data. This is because GDP deflators by sector do not measure the price of a sector's goods, but rather the value added in a sector's goods.

The concept of arbitrage for traded goods says that the prices of the traded goods, not their value added, should be equalized across countries. Using GDP deflators by sector could, therefore, generate misleading results. Other researchers have used GDP deflators to measure prices, sometimes misidentifying them as output price deflators.

A defense of using GDP deflators could be made based on their availability and their presumed similarities with $G O$ deflators. To the extent that our results vary across these two measures, however, the results based on $G O$ deflators are preferable to those based on GDP deflators on conceptual grounds. In Table A.1 we show the summary statistic values for GDP deflators, and in Table A.2 we compare the correlations between, and relative standard deviations of, the $G O$ and $G D P$ deflator measures of the relative price of nontraded goods and the real exchange rate.

Table A.1 shows the values of the summary statistics when aggregate GDP deflators are used to measure aggregate price levels, and GDP deflators for the agriculture, mining and manufacturing sectors are used to measure traded goods prices. The values of the summary statistics are generally high for Canada and Mexico and generally low for Germany and Japan. The values of the statistics for Korea represent an intermediate case, in which the variance decompositions are low but the correlations and relative standard deviations are high — at least when we detrend the data either linearly or by taking differences.

In Table A.2, we show that the aggregate real exchange rates based on $G O$ and $G D P$ deflators, respectively, are very highly correlated. This is to be expected because aggregate $G O$ deflators and aggregate $G D P$ deflators put somewhat different positive weights on sectors but are otherwise very similar objects. The measures of the relative price of nontraded goods based on these different deflator series are less correlated, 
however. The measures of $\operatorname{rer}_{i, u s}^{N}$ and $\operatorname{rer}_{i, u s}$ based on GDP deflators are also more volatile than those based on $G O$ deflators with the exception of the data from Korea.

Furthermore, comparing the statistics on the relationship between $\operatorname{rer}_{i, u s}^{N}$ and $\operatorname{rer}_{i, u s}$ based on GDP deflators in Table A.1 with the comparable statistics from the data based on $G O$ deflators in the first column of Table 3 and in Table 5, we see large differences. Notice, for example, that the correlation between $\operatorname{rer}_{i, u s}^{N}$ and $\operatorname{rer}_{i, u s}$ tends to be lower - often much lower - for the data based on GDP deflators than it is for the data based on $G O$ deflators. In short, GDP data generate different measures and hence different results than do $G O$ data. 


\section{APPENDIX B}

The five bilateral U.S. nominal exchange rates are all drawn from the International Monetary Fund's (IMF) International Financial Statistics 2001 CD-ROM. In addition, all bilateral trade data used in Table 5 are drawn from the IMF's Direction of Trade Statistics CD-ROM 2001. Some price data were drawn from a common international source, and some from country-specific sources, as we now describe.

\section{Canada}

The sectoral $G O$ data used to construct the total and traded goods' $G O$ price deflators have been purchased from Statistics Canada. The GDP data come from the OECD's STructural ANalysis (STAN) database. The CPI and PPI are taken from the IMF's International Financial Statistics 2001 CD-ROM. Data on the aggregate PCD and components are taken from the OECD's National Accounts Statistics, and the CPI by component data are from the OECD.

\section{Germany}

The aggregate and sectoral $G O$ data are from Volkswirtschaftliche Gesamtrechnungen. Reihe 1.3, Konten und Standardtabellen. Hauptbericht, various years, as are the analogous sectoral GDP data. Data on aggregate $P C D$ and components are drawn from the same source. The $C P I$ and $P P I$ are from the IMF's International Financial Statistics 2001 CD-ROM. Finally, the CPI by component data are from the Statistisches Bundesamt's Statistisches Jahrbuch 2000 für die Bundesrepublik Deutschland, 2000 and 2002.

\section{Japan}

The aggregate and sectoral GO data are from Annual Report on National Accounts (CD-ROM) of the Economic Planning Agency, Government of Japan, as are the analogous sectoral $G D P$ data. Data on aggregate $P C D$ and components are drawn from the United Nations National Accounts Statistics, various years, for the period 1980-1989, and from the OECD's National Accounts Statistics, for 1990-2000. The CPI and PPI are 
from the IMF's International Financial Statistics 2001 CD-ROM. Finally, the CPI by component data are from the OECD.

\section{Korea}

The aggregate and sectoral $G O$ data used are from the OECD's STructural ANalysis (STAN) database, as are the analogous GDP data. Data on aggregate PCD and components are drawn from the OECD's National Accounts Statistics, while the CPI and PPI are from the IMF's International Financial Statistics 2001 CD-ROM. Finally, the CPI by component data are from the Korean National Statistics Office Web site (http://www.nso.go.kr/eng/).

\section{Mexico}

The aggregate and sectoral $G O$ data for 1988-2000 are from the Web site of Instituto Nacional de Estadística, Geografía, e Informática (http://www.inegi.gob.mx/). The same data for 1980-1988 are from INEGI's 1994 Anuario Estadístico de los Estados Unidos Mexicanos. The analogous GDP data are from the same sources. The CPI and $P P I$ data are from the INEGI Web site. Data on aggregate $P C D$ and components are drawn from the United Nations' National Accounts Statistics, various years, for 19801987 and from the OECD's National Accounts Statistics for the period 1988-2000. The CPI by component data are from the OECD.

\section{United States}

The aggregate and sectoral $G O$ data are from the Bureau of Economic Analysis Web site (http://www.bea.gov/), as are the analogous sectoral GDP data. The CPI and $P P I$ are from the Bureau of Labor Statistics, and aggregate $P C D$ and components are taken from the OECD's National Accounts Statistics. The CPI by component data are from the OECD. 
TABLE 1

COMPARISON OF FREQUENCIES

CANADA-U.S. REAL EXCHANGE RATE

\section{PPI-CPI data 1980-2000}

\begin{tabular}{|c|c|c|c|c|c|c|c|c|c|}
\hline & annual & annual & quarterly & quarterly & quarterly & monthly & monthly & monthly & monthly \\
\hline $\begin{array}{l}\text { Levels } \\
\left.\text { corr(rer,rer }{ }^{\mathrm{N}}\right) \\
\operatorname{std}\left(\operatorname{rer}^{\mathrm{N}}\right) / \operatorname{std}(\text { rer }) \\
\operatorname{vardec}\left(\text { rer, } \text { rer }^{\mathrm{N}}\right)\end{array}$ & $\begin{array}{l}0.91 \\
0.57 \\
0.52\end{array}$ & & $\begin{array}{l}0.90 \\
0.57 \\
0.52\end{array}$ & & & $\begin{array}{l}0.89 \\
0.57 \\
0.51\end{array}$ & & & \\
\hline 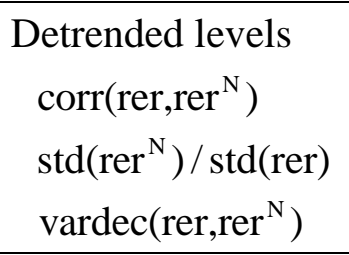 & $\begin{array}{l}0.87 \\
0.54 \\
0.45\end{array}$ & & $\begin{array}{l}0.85 \\
0.54 \\
0.45\end{array}$ & & & $\begin{array}{l}0.85 \\
0.54 \\
0.44\end{array}$ & & & \\
\hline Changes & $\begin{array}{c}1 \text { lag } \\
\text { (1 year) }\end{array}$ & $\begin{array}{c}4 \text { lags } \\
\text { (4 years) }\end{array}$ & $\begin{array}{c}1 \text { lag } \\
\text { (1 quarter) }\end{array}$ & $\begin{array}{l}4 \text { lags } \\
\text { (1 year) }\end{array}$ & $\begin{array}{l}16 \text { lags } \\
\text { (4 years) }\end{array}$ & $\begin{array}{c}1 \text { lag } \\
\text { (1 month) }\end{array}$ & $\begin{array}{c}3 \text { lags } \\
\text { (1 quarter) }\end{array}$ & $\begin{array}{l}12 \text { lags } \\
\text { (1 year) }\end{array}$ & $\begin{array}{l}48 \text { lags } \\
\text { (4 years) }\end{array}$ \\
\hline $\operatorname{corr}\left(\right.$ rer, rer $\left.^{\mathrm{N}}\right)$ & 0.62 & 0.77 & 0.56 & 0.60 & 0.83 & 0.48 & 0.52 & 0.59 & 0.82 \\
\hline
\end{tabular}


TABLE 2A

CANADA-U.S. REAL EXCHANGE RATE

Annual Data

\begin{tabular}{|c|c|c|c|c|}
\hline & $\begin{array}{c}\text { GO } \\
\text { Deflators } \\
\text { 1980-1998 }\end{array}$ & $\begin{array}{c}\text { PPI-CPI } \\
1980-2000\end{array}$ & $\begin{array}{c}\text { Components } \\
\text { of CPI } \\
1980-2000\end{array}$ & $\begin{array}{c}\text { Components } \\
\text { of PCD } \\
1980-2000\end{array}$ \\
\hline 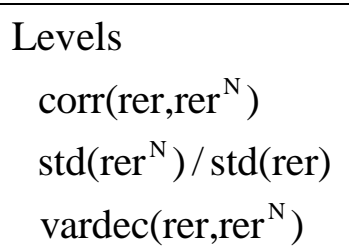 & $\begin{array}{l}0.82 \\
0.53 \\
0.40\end{array}$ & $\begin{array}{l}0.91 \\
0.57 \\
0.52\end{array}$ & $\begin{array}{l}0.45 \\
0.63 \\
0.33\end{array}$ & $\begin{array}{l}0.42 \\
0.57 \\
0.28\end{array}$ \\
\hline $\begin{array}{l}\text { Detrended levels } \\
\left.\text { corr(rer,rer }{ }^{\mathrm{N}}\right) \\
\operatorname{std}\left(\operatorname{rer}^{\mathrm{N}}\right) / \operatorname{std}(\mathrm{rer}) \\
\operatorname{vardec}\left(\text { rer, }^{\mathrm{N} e \mathrm{~N}^{\mathrm{N}}}\right)\end{array}$ & $\begin{array}{l}0.77 \\
0.46 \\
0.29\end{array}$ & $\begin{array}{l}0.87 \\
0.54 \\
0.45\end{array}$ & $\begin{array}{r}-0.45 \\
0.17 \\
0.02\end{array}$ & $\begin{array}{r}-0.30 \\
0.13 \\
0.02\end{array}$ \\
\hline $\begin{array}{l}1 \text { year changes } \\
\text { corr }\left(\text { rer,rer }{ }^{\mathrm{N}}\right) \\
\operatorname{std}\left(\operatorname{rer}^{\mathrm{N}}\right) / \text { std }(\mathrm{rer}) \\
\operatorname{vardec}\left(\text { rer,rer }^{\mathrm{N}}\right)\end{array}$ & $\begin{array}{l}0.54 \\
0.41 \\
0.19\end{array}$ & $\begin{array}{l}0.62 \\
0.59 \\
0.36\end{array}$ & $\begin{array}{r}-0.06 \\
0.21 \\
0.09\end{array}$ & $\begin{array}{r}-0.11 \\
0.13 \\
0.06\end{array}$ \\
\hline 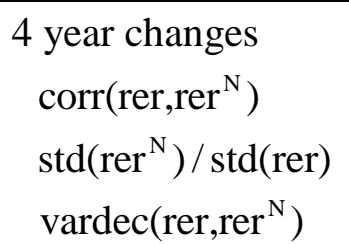 & $\begin{array}{l}0.75 \\
0.48 \\
0.31\end{array}$ & $\begin{array}{l}0.77 \\
0.59 \\
0.44\end{array}$ & $\begin{array}{r}-0.21 \\
0.16 \\
0.13\end{array}$ & $\begin{array}{l}-0.08 \\
0.13 \\
0.02\end{array}$ \\
\hline
\end{tabular}


TABLE 2B

GERMANY-U.S. REAL EXCHANGE RATE

Annual Data

\begin{tabular}{|c|c|c|c|c|}
\hline & $\begin{array}{c}\text { GO } \\
\text { Deflators } \\
\text { 1980-2000 }\end{array}$ & $\begin{array}{c}\text { PPI-CPI } \\
1980-2000\end{array}$ & $\begin{array}{c}\text { Components } \\
\text { of CPI } \\
1980-2000\end{array}$ & $\begin{array}{l}\text { Components } \\
\text { of PCD } \\
1980-2000\end{array}$ \\
\hline 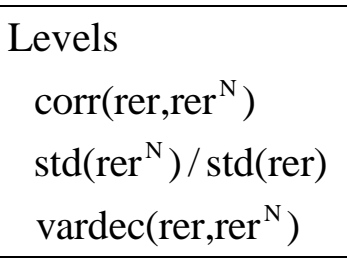 & $\begin{array}{r}-0.24 \\
0.36 \\
0.09 \\
\end{array}$ & $\begin{array}{r}-0.18 \\
0.20 \\
0.03 \\
\end{array}$ & $\begin{array}{l}-0.32 \\
0.18 \\
0.03 \\
\end{array}$ & $\begin{array}{r}-0.21 \\
0.27 \\
0.06 \\
\end{array}$ \\
\hline 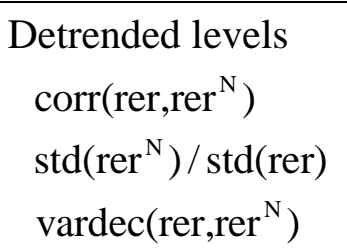 & $\begin{array}{l}0.26 \\
0.16 \\
0.03\end{array}$ & $\begin{array}{r}-0.05 \\
0.18 \\
0.03\end{array}$ & $\begin{array}{l}-0.29 \\
0.07 \\
0.01\end{array}$ & $\begin{array}{l}0.39 \\
0.11 \\
0.01\end{array}$ \\
\hline $\begin{array}{l}1 \text { year changes } \\
\text { corr }\left(\text { rer,rer }{ }^{\mathrm{N}}\right) \\
\operatorname{std}\left(\operatorname{rer}^{\mathrm{N}}\right) / \text { std }(\text { rer }) \\
\operatorname{vardec}\left(\text { rer, }_{\text {rer }}{ }^{N}\right)\end{array}$ & $\begin{array}{r}-0.03 \\
0.12 \\
0.00\end{array}$ & $\begin{array}{l}0.11 \\
0.11 \\
0.01\end{array}$ & $\begin{array}{l}-0.28 \\
0.09 \\
0.01\end{array}$ & $\begin{array}{l}0.13 \\
0.07 \\
0.01\end{array}$ \\
\hline $\begin{array}{l}4 \text { year changes } \\
\operatorname{corr}\left(\text { rer,rer }^{\mathrm{N}}\right) \\
\operatorname{std}\left(\operatorname{rer}^{\mathrm{N}}\right) / \operatorname{std}(\operatorname{rer}) \\
\operatorname{vardec}\left(\operatorname{rer}, \operatorname{rer}^{\mathrm{N}}\right)\end{array}$ & $\begin{array}{l}0.33 \\
0.17 \\
0.03\end{array}$ & $\begin{array}{l}0.08 \\
0.16 \\
0.02\end{array}$ & $\begin{array}{r}-0.34 \\
0.06 \\
0.00\end{array}$ & $\begin{array}{l}0.51 \\
0.10 \\
0.01\end{array}$ \\
\hline
\end{tabular}


TABLE 2C

JAPAN-U.S. REAL EXCHANGE RATE

Annual Data

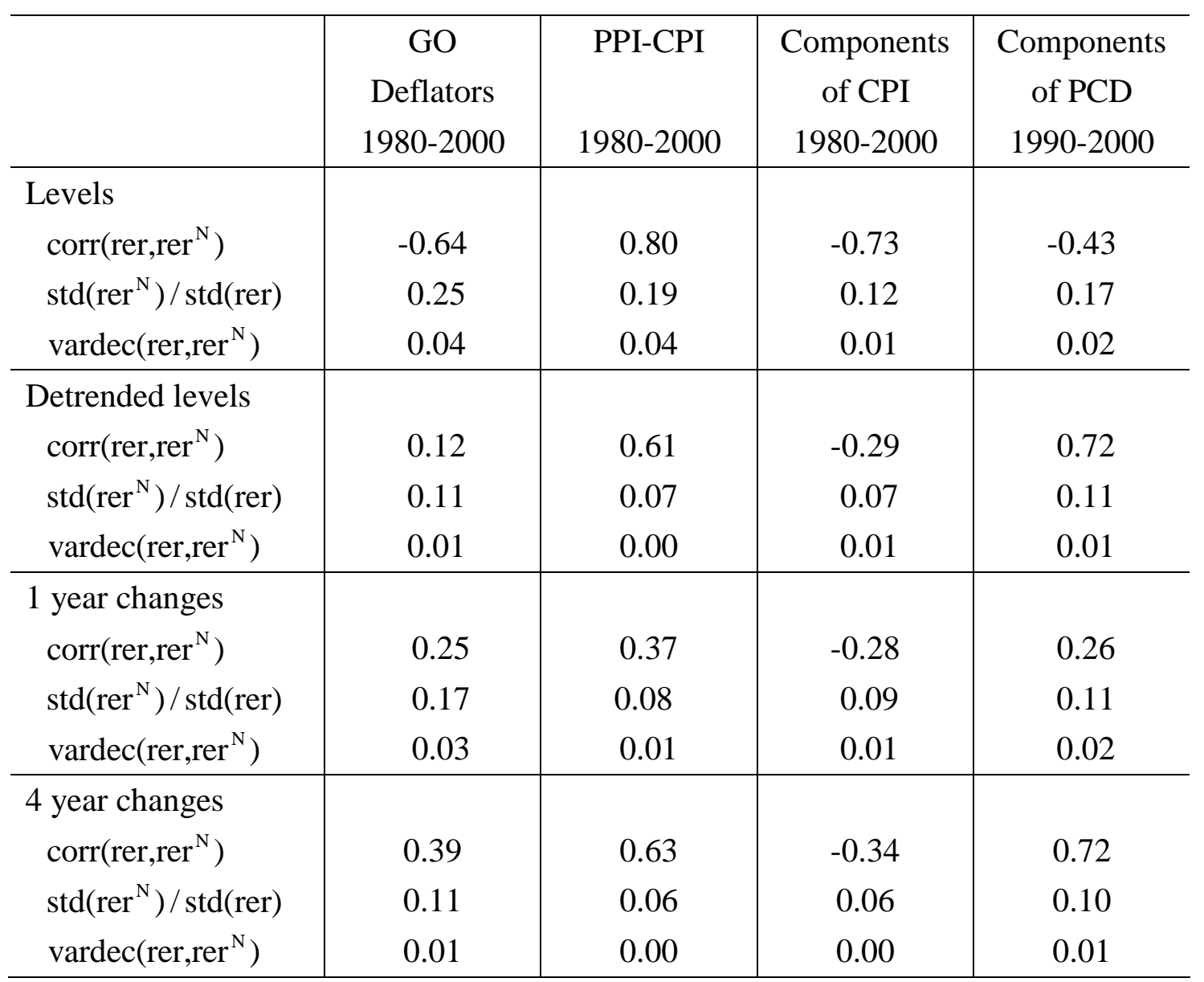


TABLE 2D

KOREA-U.S. REAL EXCHANGE RATE

Annual Data

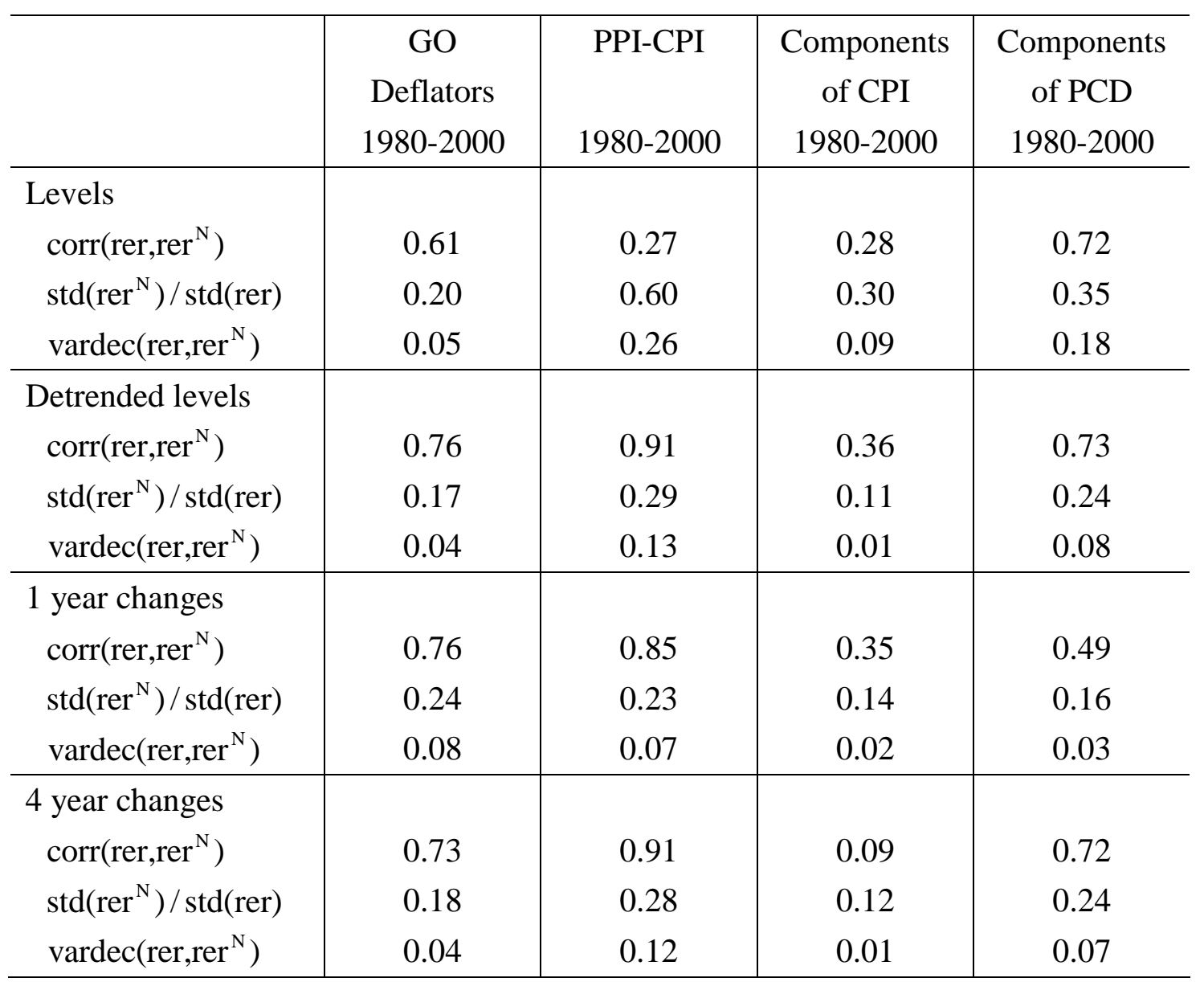


TABLE 2E

MEXICO-U.S. REAL EXCHANGE RATE

\section{Annual Data}

\begin{tabular}{|c|c|c|c|c|}
\hline & $\begin{array}{c}\text { GO } \\
\text { Deflators } \\
1980-2000\end{array}$ & $\begin{array}{c}\text { PPI-CPI } \\
1981-2000\end{array}$ & $\begin{array}{c}\text { Components } \\
\text { of CPI } \\
1982-2000\end{array}$ & $\begin{array}{c}\text { Components } \\
\text { of PCD } \\
1980-2000\end{array}$ \\
\hline \multicolumn{5}{|l|}{ Levels } \\
\hline $\operatorname{corr}\left(\mathrm{rer}, \mathrm{rer}^{\mathrm{N}}\right)$ & 0.75 & 0.74 & 0.45 & 0.81 \\
\hline $\operatorname{std}\left(\operatorname{rer}^{\mathrm{N}}\right) / \operatorname{std}($ rer $)$ & 0.37 & 0.25 & 0.44 & 0.24 \\
\hline $\operatorname{vardec}\left(\right.$ rer, $\left.\operatorname{rer}^{\mathrm{N}}\right)$ & 0.19 & 0.08 & 0.20 & 0.08 \\
\hline \multicolumn{5}{|l|}{ Detrended levels } \\
\hline $\operatorname{corr}\left(\right.$ rer, $\left.\operatorname{rer}^{\mathrm{N}}\right)$ & 0.84 & 0.70 & 0.70 & 0.85 \\
\hline $\operatorname{std}\left(\mathrm{rer}^{\mathrm{N}}\right) / \operatorname{std}(\mathrm{rer})$ & 0.37 & 0.22 & 0.53 & 0.24 \\
\hline $\operatorname{vardec}\left(\operatorname{rer}, \operatorname{rer}^{\mathrm{N}}\right)$ & 0.21 & 0.06 & 0.34 & 0.08 \\
\hline \multicolumn{5}{|l|}{1 year changes } \\
\hline $\operatorname{corr}\left(\right.$ rer, rer $\left.^{\mathrm{N}}\right)$ & 0.60 & 0.52 & 0.61 & 0.51 \\
\hline $\operatorname{std}\left(\operatorname{rer}^{\mathrm{N}}\right) / \operatorname{std}($ rer $)$ & 0.26 & 0.18 & 0.31 & 0.17 \\
\hline $\operatorname{vardec}\left(\operatorname{rer}, \operatorname{rer}^{\mathrm{N}}\right)$ & 0.08 & 0.04 & 0.12 & 0.03 \\
\hline \multicolumn{5}{|l|}{4 year changes } \\
\hline $\operatorname{corr}\left(\mathrm{rer}, \mathrm{rer}^{\mathrm{N}}\right)$ & 0.90 & 0.80 & 0.77 & 0.92 \\
\hline $\operatorname{std}\left(\right.$ rer $\left.^{\mathrm{N}}\right) / \operatorname{std}($ rer $)$ & 0.39 & 0.27 & 0.52 & 0.27 \\
\hline $\operatorname{vardec}\left(\right.$ rer, $\left.\operatorname{rer}^{N}\right)$ & 0.25 & 0.13 & 0.36 & 0.11 \\
\hline
\end{tabular}


TABLE 3

COMPARISON OF SERIES

TRADE WEIGHTED AVERAGE

\section{Annual Data}

\begin{tabular}{|c|c|c|c|c|}
\hline & $\begin{array}{c}\text { GO } \\
\text { Deflators }\end{array}$ & PPI-CPI & $\begin{array}{c}\text { Components } \\
\text { of CPI }\end{array}$ & $\begin{array}{c}\text { Components } \\
\text { of PCD }\end{array}$ \\
\hline \multicolumn{5}{|l|}{ Levels } \\
\hline corr(rer,rer $\left.{ }^{\mathrm{N}}\right)$ & 0.41 & 0.71 & 0.14 & 0.31 \\
\hline $\operatorname{std}\left(\operatorname{rer}^{\mathrm{N}}\right) / \operatorname{std}($ rer $)$ & 0.40 & 0.38 & 0.42 & 0.36 \\
\hline $\operatorname{vardec}\left(\right.$ rer,rer $\left.{ }^{\mathrm{N}}\right)$ & 0.23 & 0.26 & 0.19 & 0.15 \\
\hline \multicolumn{5}{|l|}{ Detrended levels } \\
\hline $\operatorname{corr}\left(\right.$ rer,rer $\left.{ }^{\mathrm{N}}\right)$ & 0.61 & 0.70 & 0.01 & 0.31 \\
\hline $\operatorname{std}\left(\operatorname{rer}^{N}\right) / \operatorname{std}($ rer $)$ & 0.32 & 0.32 & 0.24 & 0.16 \\
\hline $\operatorname{vardec}\left(\right.$ rer, rer $\left.^{\mathrm{N}}\right)$ & 0.18 & 0.21 & 0.10 & 0.04 \\
\hline \multicolumn{5}{|l|}{1 year changes } \\
\hline $\operatorname{corr}\left(\right.$ rer, rer $\left.^{\mathrm{N}}\right)$ & 0.46 & 0.52 & 0.05 & 0.18 \\
\hline $\operatorname{std}\left(\operatorname{rer}^{N}\right) / \operatorname{std}($ rer $)$ & 0.29 & 0.32 & 0.20 & 0.14 \\
\hline $\operatorname{vardec}\left(\right.$ rer,rer $\left.{ }^{\mathrm{N}}\right)$ & 0.11 & 0.16 & 0.07 & 0.04 \\
\hline \multicolumn{5}{|l|}{4 year changes } \\
\hline $\operatorname{corr}\left(\right.$ rer, rer $\left.^{\mathrm{N}}\right)$ & 0.68 & 0.70 & 0.04 & 0.43 \\
\hline $\operatorname{std}\left(\operatorname{rer}^{\mathrm{N}}\right) / \operatorname{std}($ rer $)$ & 0.34 & 0.34 & 0.23 & 0.16 \\
\hline $\operatorname{vardec}\left(\right.$ rer,rer $\left.{ }^{\mathrm{N}}\right)$ & 0.19 & 0.21 & 0.10 & 0.04 \\
\hline
\end{tabular}


TABLE 4

COMPARISON OF SERIES
CORRELATIONS OF DIFFERENT MEASURES OF $\mathrm{rer}^{N}$

Annual Data

\begin{tabular}{|c|c|c|c|c|c|c|}
\hline & Canada & Germany & Japan & Korea & Mexico & $\begin{array}{l}\text { weighted } \\
\text { average }\end{array}$ \\
\hline \multicolumn{7}{|l|}{ Levels } \\
\hline PPI-CPI/GO deflator & 0.93 & 0.35 & 0.11 & -0.53 & 0.66 & 0.56 \\
\hline CPI components/GO deflator & 0.61 & 0.84 & 0.05 & 0.87 & 0.80 & 0.57 \\
\hline PCD components/GO deflator & 0.61 & 0.99 & 0.87 & -0.37 & 0.94 & 0.72 \\
\hline PCD components/CPI components & 0.996 & 0.82 & 0.07 & -0.61 & 0.87 & 0.66 \\
\hline \multicolumn{7}{|l|}{ Detrended levels } \\
\hline CPI-PPI/GO deflator & 0.94 & 0.81 & 0.34 & 0.81 & 0.62 & 0.72 \\
\hline CPI components/GO deflator & -0.13 & 0.36 & 0.18 & 0.52 & 0.65 & 0.21 \\
\hline PCD components/GO deflator & -0.08 & 0.93 & 0.32 & 0.82 & 0.74 & 0.35 \\
\hline PCD components/CPI components & 0.91 & 0.31 & 0.31 & 0.61 & 0.95 & 0.73 \\
\hline \multicolumn{7}{|l|}{1 year changes } \\
\hline CPI-PPI/GO deflator & 0.89 & 0.67 & 0.38 & 0.77 & 0.59 & 0.69 \\
\hline CPI components/GO deflator & -0.22 & 0.66 & 0.05 & 0.32 & 0.84 & 0.21 \\
\hline PCD components/GO deflator & -0.18 & 0.75 & 0.19 & 0.46 & 0.86 & 0.27 \\
\hline PCD components/CPI components & 0.79 & 0.61 & 0.09 & 0.55 & 0.89 & 0.64 \\
\hline \multicolumn{7}{|l|}{4 year changes } \\
\hline CPI-PPI/GO deflator & 0.95 & 0.80 & 0.64 & 0.84 & 0.79 & 0.83 \\
\hline CPI components/GO deflator & 0.08 & 0.75 & 0.00 & 0.48 & 0.90 & 0.35 \\
\hline PCD components/GO deflator & 0.09 & 0.92 & 0.42 & 0.81 & 0.97 & 0.49 \\
\hline PCD components/CPI components & 0.87 & 0.70 & 0.17 & 0.62 & 0.94 & 0.72 \\
\hline
\end{tabular}


TABLE 5

COMPARISON OF COUNTRIES

GROSS OUTPUT DEFLATORS

Annual Data

\begin{tabular}{|c|c|c|c|c|c|}
\hline & Canada & Germany & Japan & Korea & Mexico \\
\hline \multicolumn{6}{|l|}{ Importance of trade to country $i$} \\
\hline 2000 bilateral trade/GDP & 0.58 & 0.05 & 0.04 & 0.14 & 0.44 \\
\hline 2000 bilateral trade/trade & 0.83 & 0.08 & 0.26 & 0.20 & 0.83 \\
\hline Rank of U.S. as partner & 1 & 3 & 1 & 1 & 1 \\
\hline \multicolumn{6}{|l|}{ Importance of trade to U.S. } \\
\hline 2000 bilateral trade/U.S. GDP & 0.04 & 0.01 & 0.02 & 0.01 & 0.03 \\
\hline 2000 bilateral trade/U.S. trade & 0.21 & 0.04 & 0.11 & 0.03 & 0.13 \\
\hline Rank of country $i$ as partner & 1 & 6 & 3 & 7 & 2 \\
\hline \multicolumn{6}{|l|}{ Levels } \\
\hline $\operatorname{corr}\left(\right.$ rer, rer $\left.^{\mathrm{N}}\right)$ & 0.82 & -0.24 & -0.64 & 0.61 & 0.75 \\
\hline $\operatorname{std}\left(\right.$ rer $\left.^{N}\right) / \operatorname{std}($ rer $)$ & 0.53 & 0.36 & 0.25 & 0.20 & 0.37 \\
\hline $\operatorname{vardec}\left(\right.$ rer,rer $\left.{ }^{\mathrm{N}}\right)$ & 0.40 & 0.09 & 0.04 & 0.05 & 0.19 \\
\hline \multicolumn{6}{|l|}{ Detrended levels } \\
\hline $\operatorname{corr}\left(\right.$ rer, rer $\left.^{\mathrm{N}}\right)$ & 0.77 & 0.26 & 0.12 & 0.76 & 0.84 \\
\hline $\operatorname{std}\left(\operatorname{rer}^{\mathrm{N}}\right) / \operatorname{std}($ rer $)$ & 0.46 & 0.16 & 0.11 & 0.17 & 0.37 \\
\hline $\operatorname{vardec}\left(\right.$ rer,rer $\left.{ }^{\mathrm{N}}\right)$ & 0.29 & 0.03 & 0.01 & 0.04 & 0.21 \\
\hline \multicolumn{6}{|l|}{1 year changes } \\
\hline $\operatorname{corr}\left(\right.$ rer, $\left.\operatorname{rer}^{\mathrm{N}}\right)$ & 0.55 & -0.03 & 0.25 & 0.76 & 0.60 \\
\hline $\operatorname{std}\left(\right.$ rer $\left.^{N}\right) / \operatorname{std}($ rer $)$ & 0.41 & 0.12 & 0.17 & 0.24 & 0.26 \\
\hline $\operatorname{vardec}\left(\right.$ rer,rer $\left.{ }^{\mathrm{N}}\right)$ & 0.19 & 0.02 & 0.02 & 0.08 & 0.08 \\
\hline \multicolumn{6}{|l|}{4 year changes } \\
\hline $\operatorname{corr}\left(\right.$ rer, rer $\left.^{\mathrm{N}}\right)$ & 0.75 & 0.33 & 0.39 & 0.73 & 0.90 \\
\hline $\operatorname{std}\left(\right.$ rer $\left.^{N}\right) / \operatorname{std}($ rer $)$ & 0.48 & 0.17 & 0.11 & 0.25 & 0.39 \\
\hline $\operatorname{vardec}\left(\operatorname{rer}, \operatorname{rer}^{\mathrm{N}}\right)$ & 0.31 & 0.03 & 0.01 & 0.08 & 0.25 \\
\hline
\end{tabular}


TABLE A.1

GROSS DOMESTIC PRODUCT DEFLATORS

Annual Data

\begin{tabular}{|c|c|c|c|c|c|c|}
\hline & $\begin{array}{c}\text { Canada } \\
1980-1998\end{array}$ & $\begin{array}{c}\text { Germany } \\
1980-2000\end{array}$ & $\begin{array}{c}\text { Japan } \\
1980-2000 \\
\end{array}$ & $\begin{array}{c}\text { Korea } \\
1980-2000 \\
\end{array}$ & $\begin{array}{c}\text { Mexico } \\
1980-2000 \\
\end{array}$ & $\begin{array}{l}\text { weighted } \\
\text { average }\end{array}$ \\
\hline \multicolumn{7}{|l|}{ Levels } \\
\hline $\operatorname{corr}\left(\right.$ rer, rer $\left.^{\mathrm{N}}\right)$ & 0.78 & -0.33 & -0.69 & -0.01 & 0.72 & 0.33 \\
\hline $\operatorname{std}\left(\operatorname{rer}^{\mathrm{N}}\right) / \operatorname{std}($ rer $)$ & 0.78 & 0.54 & 0.20 & 0.26 & 0.54 & 0.55 \\
\hline $\operatorname{vardec}\left(\right.$ rer,rer $\left.{ }^{\mathrm{N}}\right)$ & 0.61 & 0.15 & 0.03 & 0.06 & 0.36 & 0.36 \\
\hline \multicolumn{7}{|l|}{ Detrended levels } \\
\hline $\operatorname{corr}\left(\right.$ rer, rer $\left.^{\mathrm{N}}\right)$ & 0.66 & 0.16 & 0.27 & 0.48 & 0.87 & 0.47 \\
\hline $\operatorname{std}\left(\operatorname{rer}^{N}\right) / \operatorname{std}($ rer $)$ & 0.66 & 0.25 & 0.17 & 0.18 & 0.49 & 0.55 \\
\hline $\operatorname{vardec}\left(\right.$ rer,rer $\left.{ }^{\mathrm{N}}\right)$ & 0.43 & 0.06 & 0.03 & 0.04 & 0.35 & 0.27 \\
\hline \multicolumn{7}{|l|}{1 year changes } \\
\hline $\operatorname{corr}\left(\right.$ rer, rer $\left.^{\mathrm{N}}\right)$ & 0.11 & -0.22 & -0.24 & 0.60 & 0.56 & 0.15 \\
\hline $\operatorname{std}\left(\operatorname{rer}^{N}\right) / \operatorname{std}($ rer $)$ & 0.77 & 0.18 & 0.17 & 0.27 & 0.37 & 0.47 \\
\hline $\operatorname{vardec}\left(\operatorname{rer}, \operatorname{rer}^{\mathrm{N}}\right)$ & 0.32 & 0.04 & 0.03 & 0.09 & 0.16 & 0.18 \\
\hline \multicolumn{7}{|l|}{4 year changes } \\
\hline $\operatorname{corr}\left(\right.$ rer,rer $\left.{ }^{\mathrm{N}}\right)$ & 0.67 & 0.14 & -0.17 & 0.52 & 0.91 & 0.51 \\
\hline $\operatorname{std}\left(\operatorname{rer}^{\mathrm{N}}\right) / \operatorname{std}($ rer $)$ & 0.70 & 0.26 & 0.15 & 0.19 & 0.36 & 0.45 \\
\hline $\operatorname{vardec}\left(\operatorname{rer}, \operatorname{rer}^{\mathrm{N}}\right)$ & 0.47 & 0.06 & 0.02 & 0.04 & 0.36 & 0.29 \\
\hline
\end{tabular}


TABLE A.2

COMPARISON OF GROSS DOMESTIC PRODUCT DEFLATORS AND GROSS OUTPUT DEFLATORS

Annual Data

\begin{tabular}{|c|c|c|c|c|c|c|}
\hline & $\begin{array}{c}\text { Canada } \\
1980-1998\end{array}$ & $\begin{array}{c}\text { Germany } \\
1980-2000\end{array}$ & $\begin{array}{c}\text { Japan } \\
1980-2000\end{array}$ & $\begin{array}{c}\text { Korea } \\
1980-2000\end{array}$ & $\begin{array}{c}\text { Mexico } \\
1980-2000\end{array}$ & $\begin{array}{l}\text { weighted } \\
\text { average }\end{array}$ \\
\hline \multicolumn{7}{|l|}{ Levels } \\
\hline corr(rer(GDP),rer(GO)) & 0.992 & 0.997 & 0.998 & 0.94 & 0.99 & 0.99 \\
\hline $\operatorname{corr}\left(\operatorname{rer}^{\mathrm{N}}(\mathrm{GDP}), \operatorname{rer}^{\mathrm{N}}(\mathrm{GO})\right)$ & 0.97 & 0.99 & 0.83 & 0.90 & 0.95 & 0.93 \\
\hline $\operatorname{std}(\operatorname{rer}(\mathrm{GDP})) / \operatorname{std}(\operatorname{rer}(\mathrm{GO}))$ & 1.23 & 1.11 & 1.14 & 1.37 & 1.14 & 1.19 \\
\hline $\operatorname{std}\left(\operatorname{rer}^{\mathrm{N}}(\mathrm{GDP})\right) / \operatorname{std}\left(\operatorname{rer}^{\mathrm{N}}(\mathrm{GO})\right)$ & 1.77 & 1.68 & 0.88 & 1.74 & 1.65 & 1.55 \\
\hline \multicolumn{7}{|l|}{ Detrended levels } \\
\hline corr(rer(GDP),rer(GO)) & 0.991 & 0.998 & 0.997 & 0.993 & 0.994 & 0.994 \\
\hline $\operatorname{corr}\left(\operatorname{rer}^{\mathrm{N}}(\mathrm{GDP}), \operatorname{rer}^{\mathrm{N}}(\mathrm{GO})\right)$ & 0.95 & 0.94 & 0.37 & 0.92 & 0.98 & 0.84 \\
\hline std(rer(GDP))/std(rer(GO)) & 1.13 & 1.08 & 1.10 & 1.25 & 1.16 & 1.14 \\
\hline $\operatorname{std}\left(\operatorname{rer}^{\mathrm{N}}(\mathrm{GDP})\right) / \operatorname{std}\left(\operatorname{rer}^{\mathrm{N}}(\mathrm{GO})\right)$ & 1.63 & 1.66 & 1.72 & 1.33 & 1.47 & 1.59 \\
\hline \multicolumn{7}{|l|}{1 year changes } \\
\hline corr(rer(GDP),rer(GO)) & 0.99 & 0.998 & 0.997 & 0.993 & 0.994 & 0.993 \\
\hline $\operatorname{corr}\left(\operatorname{rer}^{\mathrm{N}}(\mathrm{GDP}), \operatorname{rer}^{\mathrm{N}}(\mathrm{GO})\right)$ & 0.88 & 0.80 & 0.45 & 0.89 & 0.92 & 0.80 \\
\hline $\operatorname{std}(\operatorname{rer}(\mathrm{GDP})) / \operatorname{std}(\operatorname{rer}(\mathrm{GO}))$ & 1.11 & 1.08 & 1.08 & 1.21 & 1.08 & 1.10 \\
\hline $\operatorname{std}\left(\operatorname{rer}^{\mathrm{N}}(\mathrm{GDP})\right) / \operatorname{std}\left(\operatorname{rer}^{\mathrm{N}}(\mathrm{GO})\right)$ & 2.04 & 1.65 & 1.11 & 1.39 & 1.54 & 1.66 \\
\hline \multicolumn{7}{|l|}{4 year changes } \\
\hline corr(rer(GDP),rer(GO)) & 0.994 & 0.998 & 0.998 & 0.995 & 0.995 & 0.996 \\
\hline $\operatorname{corr}\left(\operatorname{rer}^{\mathrm{N}}(\mathrm{GDP}), \operatorname{rer}^{\mathrm{N}}(\mathrm{GO})\right)$ & 0.97 & 0.93 & 0.22 & 0.94 & 0.98 & 0.81 \\
\hline std(rer(GDP))/std(rer(GO)) & 1.08 & 1.09 & 1.09 & 1.22 & 1.17 & 1.11 \\
\hline $\operatorname{std}\left(\operatorname{rer}^{\mathrm{N}}(\mathrm{GDP})\right) / \operatorname{std}\left(\operatorname{rer}^{\mathrm{N}}(\mathrm{GO})\right)$ & 1.56 & 1.69 & 1.46 & 1.28 & 1.39 & 1.49 \\
\hline
\end{tabular}


FIGURE 1

U.S. BILATERAL REAL EXCHANGE RATES AND RELATIVE PRICES OF NONTRADED GOODS

Germay-U.S. Real Exchange Rate

Monthly CPI/PPI

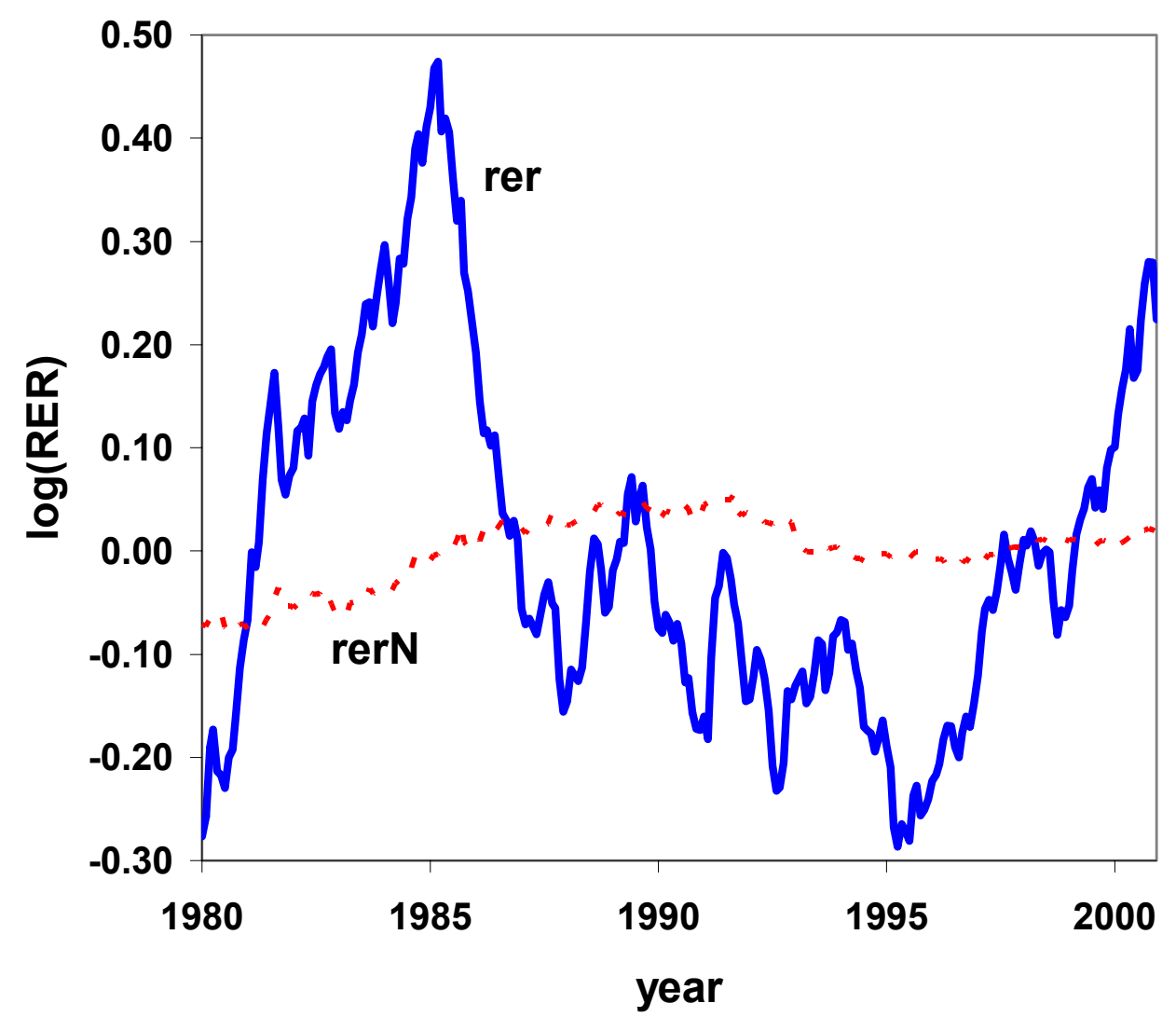

Canada-U.S. Real Exchange Rate Monthly CPI/PPI

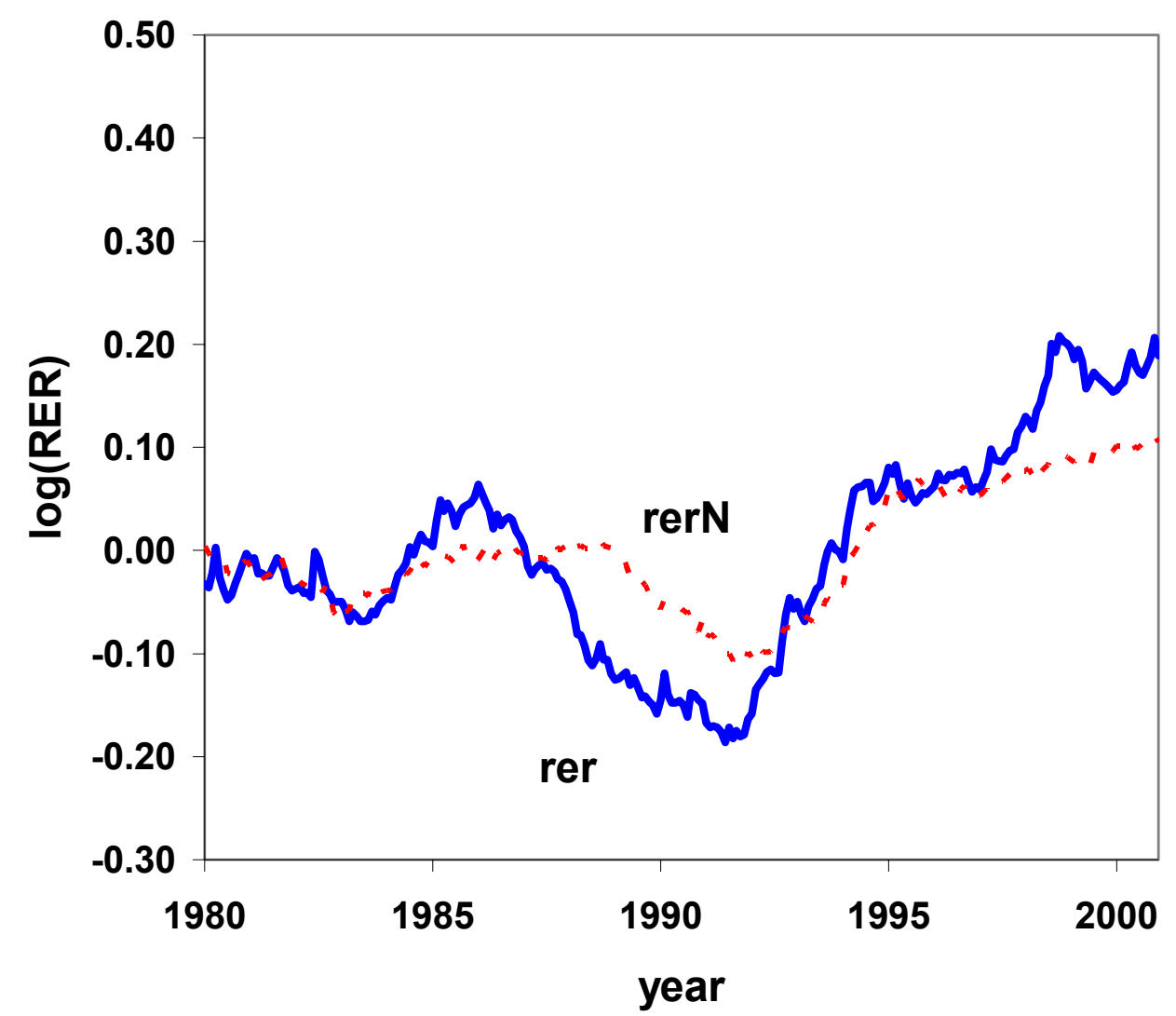


FIGURE 2

CANADA-U.S. REAL EXCHANGE RATE

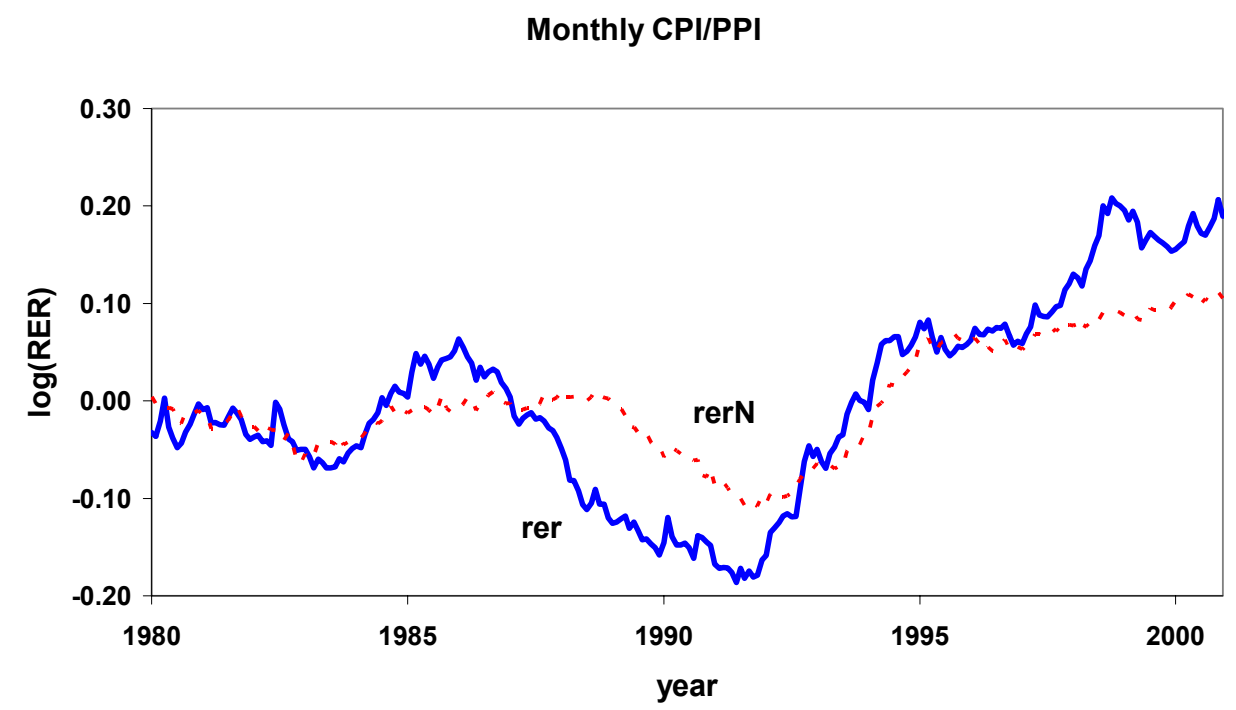

Quarterly CPI/PPI

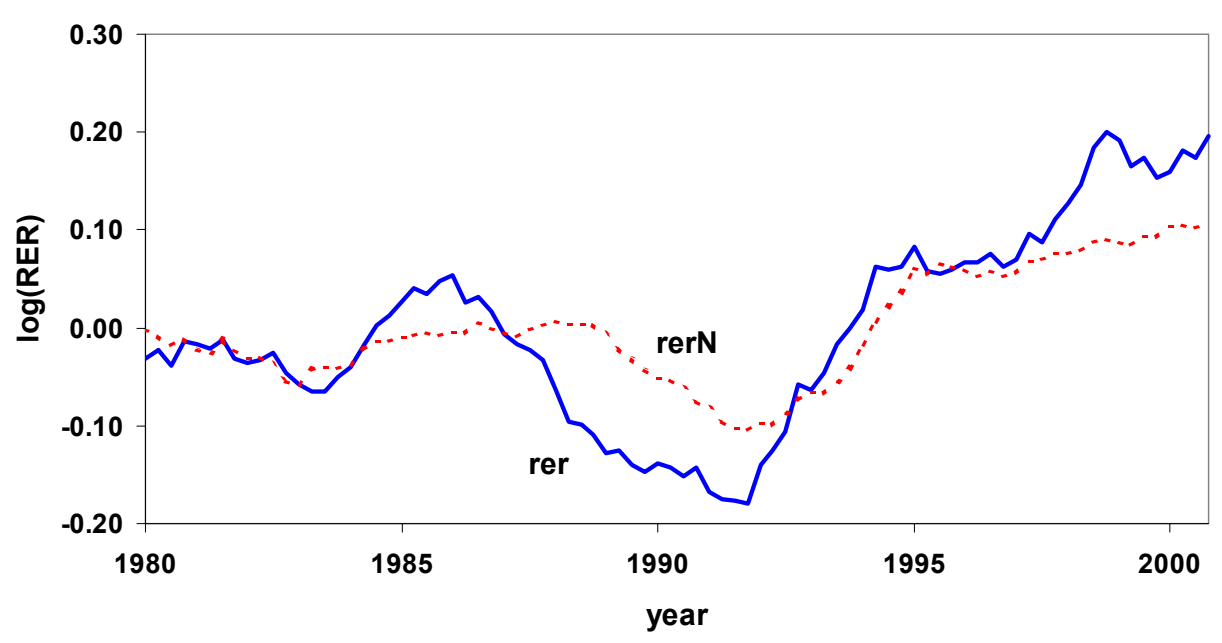

Annual CPI/PPI

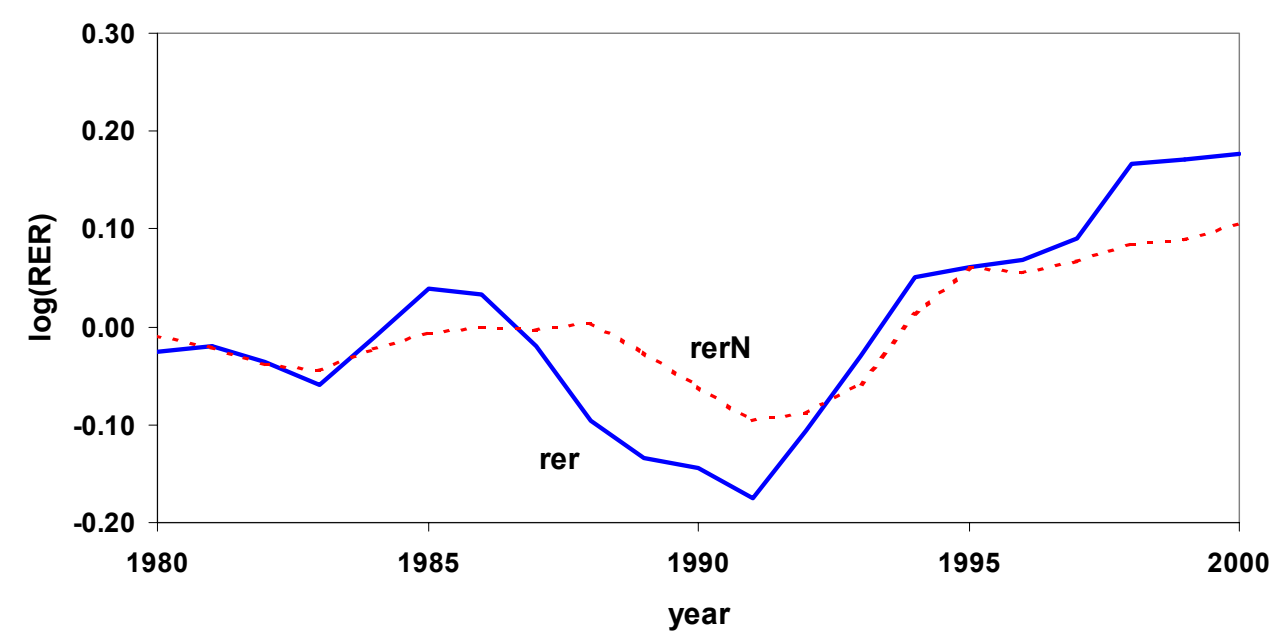


FIGURE 3A

C ANADA-U.S. REAL EXCHANGE RATE
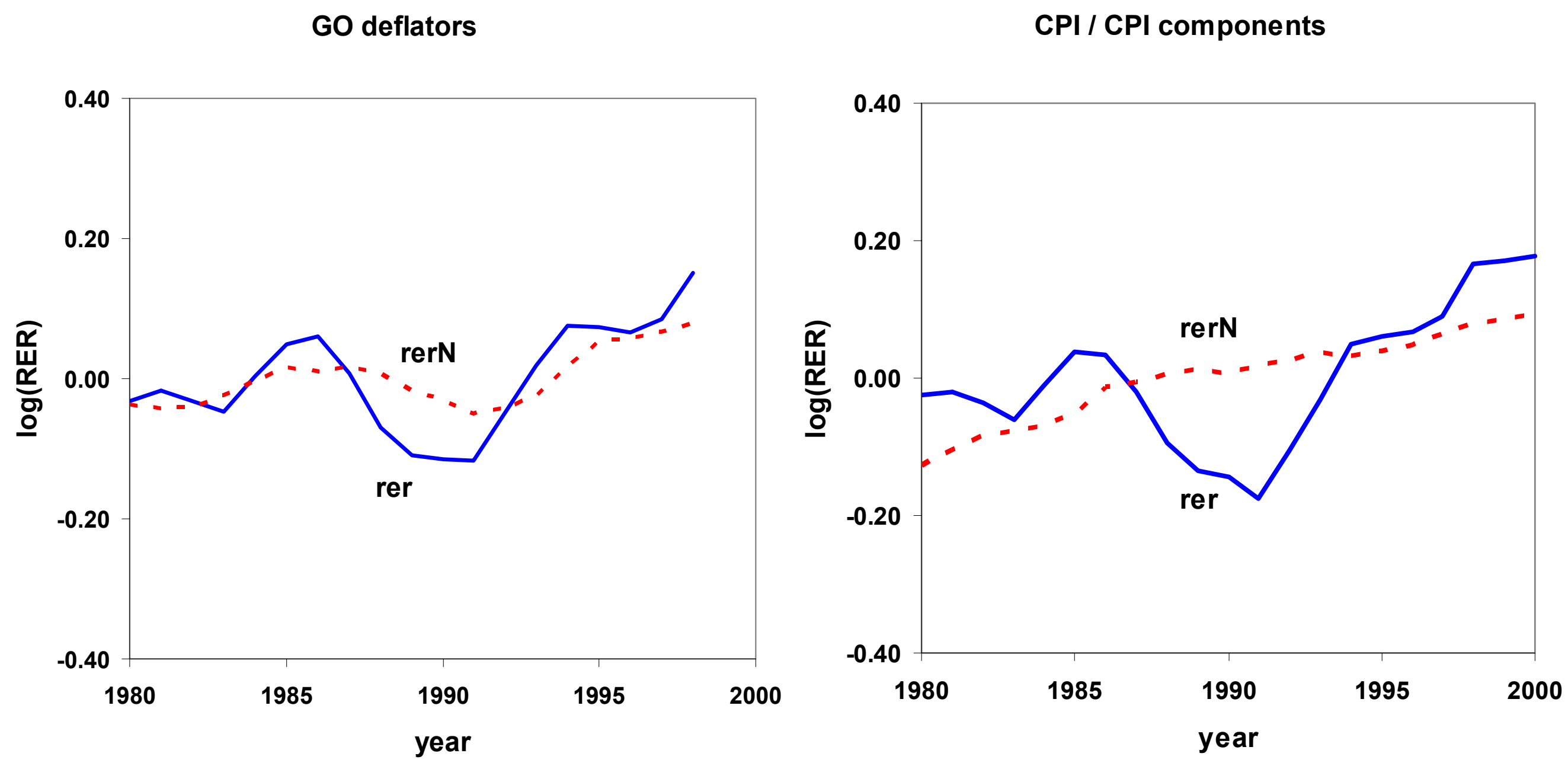


\section{FIGURE 3B}

\section{GERMANY-U.S. REAL EXCHANGE RATE}
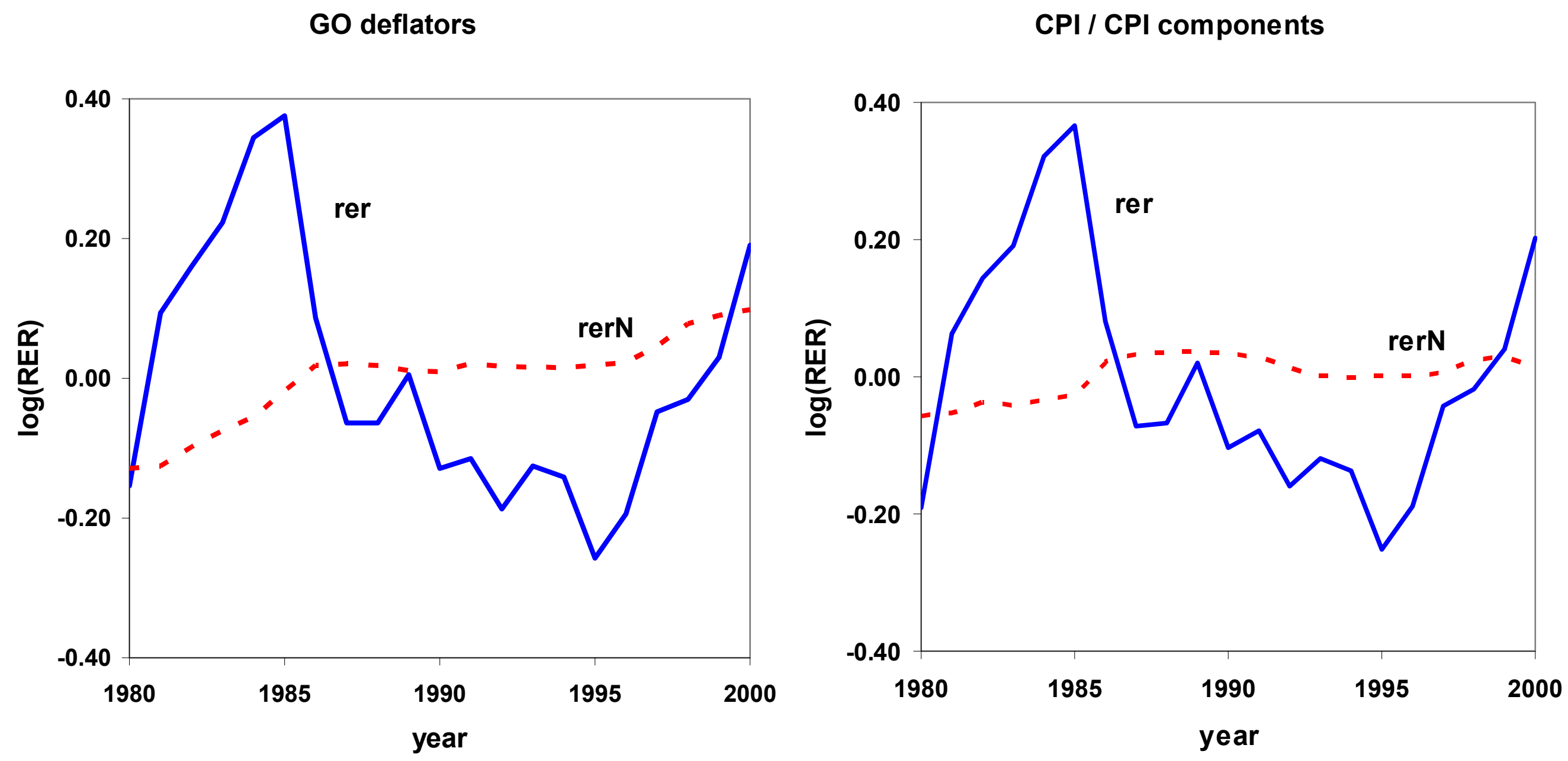
FIGURE BC

JAPAN-U.S. REAL EXCHANGE RATE

GO deflators

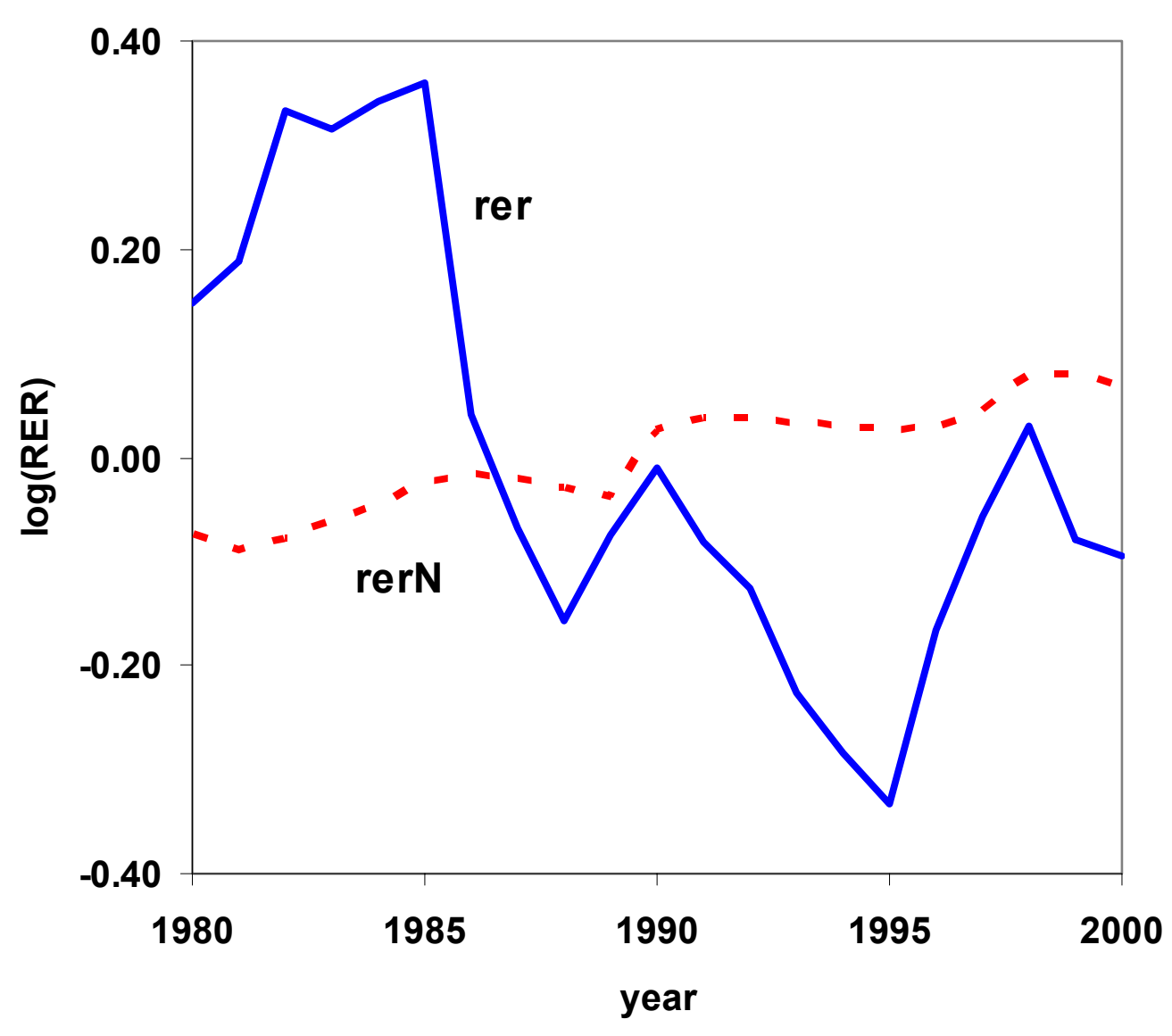

CPI / CPI components

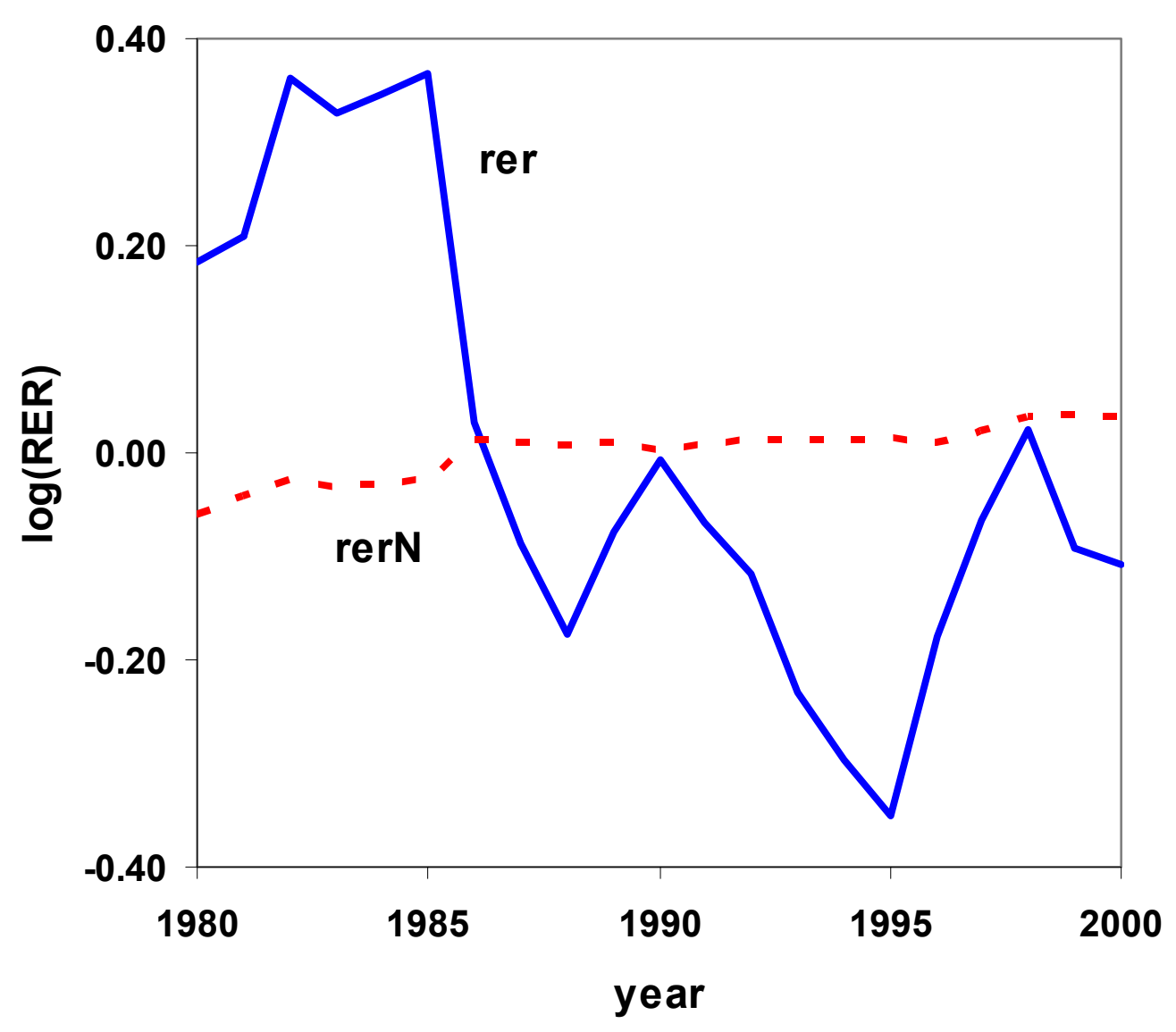


FIGURE 3D

KOREA-U.S. REAL EXCHANGE RATE

GO deflators

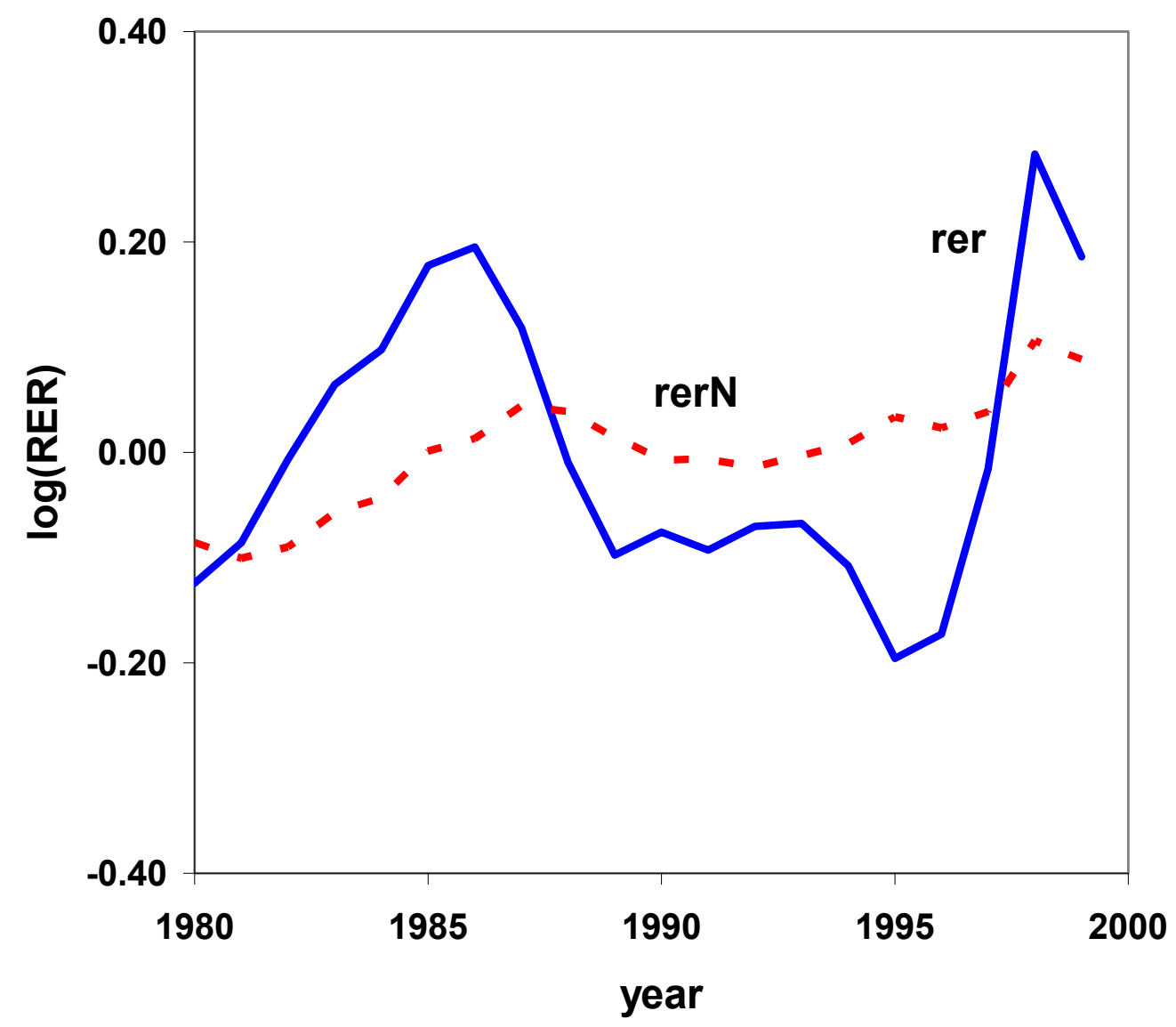

CPI / CPI components

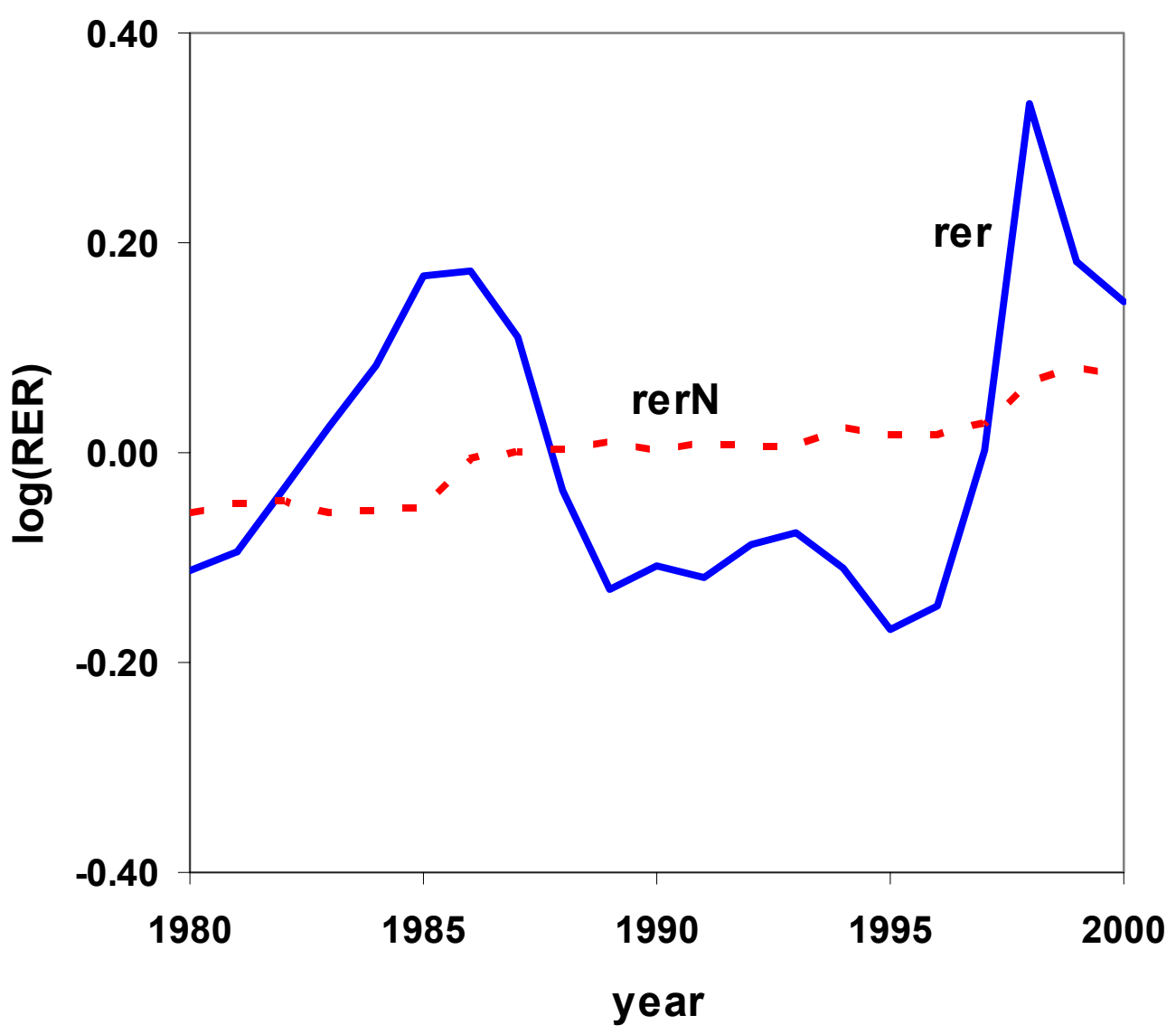


FIGURE 3E

MEXICO-U.S. REAL EXCHANGE RATE
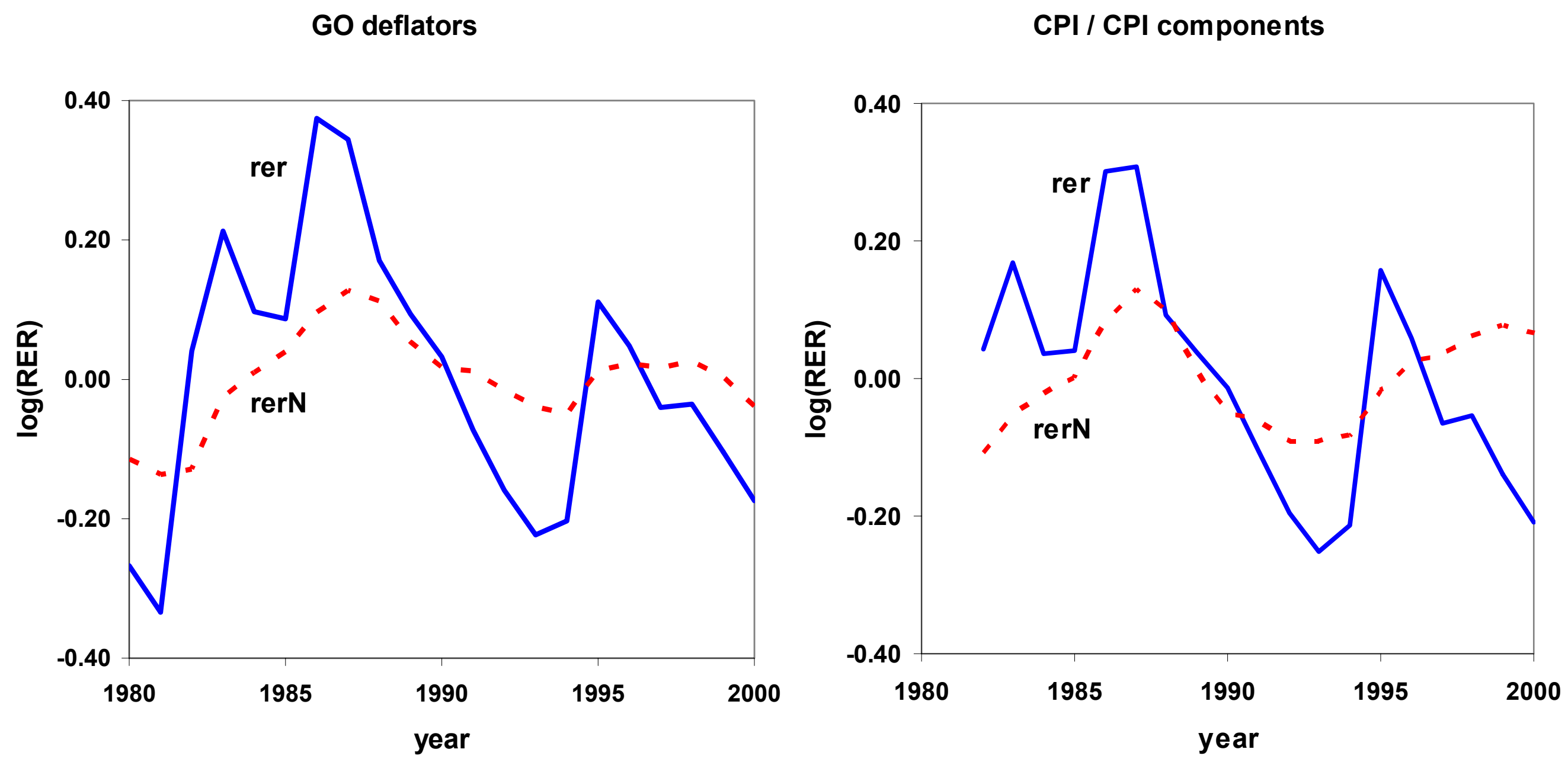